\title{
Ceratocystis species, including two new species associated with nitidulid beetles on eucalypt in Australia
}

\author{
Kamgan Nkuekam Gilbert ${ }^{*}$, Michael J. Wingfield ${ }^{1}$, Caroline Mohammed ${ }^{2}$, Angus J. Carnegie ${ }^{3}$, Geoff \\ S. Pegg ${ }^{4} \&$ Jolanda Roux ${ }^{1}$
}

\footnotetext{
${ }^{1}$ Department of Microbiology and Plant Pathology, DST/NRF Centre of Excellence in Tree Health Biotechnology, Forestry and Agricultural Biotechnology Institute (FABI), University of Pretoria, Private bag X20 Hatfield, Pretoria 0038, Pretoria, South Africa.

${ }^{2}$ School of Agricultural Science, University of Tasmania, GPO Box 252-54, Hobart TAS 7001, Australia

${ }^{3}$ Forest Science Centre, Industry \& Investment NSW, PO Box 100 Beecroft NSW 2119, Australia

${ }^{4}$ Agric-Science Queensland, Gate 3, 80 Meiers Road, Indooroopilly, Qld 4068, Australia
}

\begin{abstract}
The genus Ceratocystis includes important fungal pathogens of trees, including Eucalyptus spp. Ironically, very little is known regarding the diversity or biology of Ceratocystis species on Eucalyptus species in Australia, where most of these trees are native. The aim of this study was to survey for Ceratocystis spp., and their possible insect associates on eucalypts in Australia and thus, to establish a foundation of knowledge regarding these fungi on the continent. Collections were made in three states of Australia from wounds on trees, as well as from nitidulid beetles associated with these wounds. Ceratocystis spp. were identified based on morphology and multigene sequence comparisons. Of the 54 isolates obtained, two previously unknown species of Ceratocystis were found and these are described here as $C$. corymbiicola sp. nov. and C. tyalla sp. nov. Furthermore, the distribution of $C$. pirilliformis is expanded to include Eucalyptus spp. in Tasmania.
\end{abstract}

Keywords Brachypeplus, Carpophilus, Corymbia, Eucalyptus, fungal diversity, plantation forestry. Jolanda.roux@fabi.up.ac.za

\section{Introduction}

The genus Ceratocystis includes important insect-associated pathogens of agricultural and forestry crops, worldwide (Kile 1993; Roux and Wingfield 2009). Disease symptoms associated with infection by these fungi include stem cankers, root and fruit rot, wood stain and vascular wilt. The type species of the genus, C. fimbriata Ellis \& Halsted, is best known as the causal agent of sweet potato black rot disease (Halsted 1890; Halsted and Fairchild 1891). However, in the past two decades Ceratocystis species have emerged as important threats to plantation forestry trees, causing diseases of Eucalyptus species, Acacia mearnsii de Wild and A. mangium Wild trees in non-native plantation situations (Roux \& Wingfield 2009; Tarigan et al. 2010). Important examples include C. fimbriata sensu lato (s.l.) reported to cause wilt and death of Eucalyptus spp. in the Republic of Congo, Uganda, Uruguay and Brazil (Barnes et al. 2003a; Roux et al. 1999; 2000; 2001), and C. albifundus De Beer, Wingfield \& Morris that causes a serious wilt disease of plantation-grown A. mearnsii trees in South Africa 
(Morris et al. 1993; Wingfield et al. 1996; Roux and Wingfield 2009) and C. acaciivora Tarigan \& M. van Wyk the cause of wilt and death of A. mangium in Indonesia (Tarigan et al. 2010).

The eucalypts include more than 700 tree species distributed in the genera, Eucalyptus L'Her. Corymbia K.D. Hill \& L.A.S. Johnson and Angophora Cav. (Hill and Johnson 1995). Many of these trees are grown as non-natives in commercial plantations and woodlots, covering more than 20 million hectares in more than 60 countries (Iglesias-Trabado and Wilstermann 2008). In Australia, numerous indigenous fungi are found on these trees and none have been reported to cause major disease in native forest situations (Keane et al. 2000; Park et al. 2000; Carnegie et al. 2007). In contrast, where eucalypts are planted as non-natives in plantations, there have been multiple reports of diseases of these trees (Keane et al. 2000; Wingfield 2003; Wingfield et al. 2008). These include disease caused by, or associated with Ceratocystis species (Roux and Wingfield 2009).

A number of Ceratocystis spp. have been reported from Australia infecting wounds on Eucalyptus trees. These include $C$. eucalypti Z.Q. Yuan \& Kile that causes vascular stain on E. regnans F. Muell., E. sieberi L.A.S. Johnson and E. globoidea Blakely (Kile et al. 1996), C. pirilliformis I. Barnes \& M.J. Wingf. causing sap-stain on Eucalyptus species (Barnes et al. 2003b; Kamgan Nkuekam et al. 2009), C. moniliformopsis Yuan \& Mohammed infecting E. obliqua L'Her (Yuan and Mohammed 2002), C. moniliformis (Hedgcock) Moreau from E. grandis (Hill) Maiden (Fouche et al. 2007) and C. atrox M. Van Wyk \& M.J. Wingfield found in the galleries of Phoracantha acanthocera Macleay (Coleoptera: Cerambycidae) infesting E. grandis (Van Wyk et al. 2007). These reports have all been from very limited studies. Based on these and the recent descriptions of numerous previously undescribed species of Ceratocystis from Eucalyptus elsewhere in the world, it is likely that many more species await discovery on eucalypts in Australia. A recent study on C. pirilliformis, using polymorphic simple sequence repeat (SSR) markers, for example, suggests that this fungus was introduced to South Africa (Kamgan Nkuekam et al. 2009) and it might be native to Australia (Barnes et al. 2003b; Kamgan Nkuekam et al. 2009) where it was first discovered.

Ceratocystis species commonly have associations with insects, particularly bark beetles (Furniss et al. 1990; Harrington and Wingfield 1998; Redfern et al. 1987; Wingfield et al. 1997) and nitidulid beetles (Cease and Juzwik 2001; Moller and Devay 1968). These associations have been broadly classified into "specific" associations, such as that of the conifer pathogens, C. polonica (Siemaszko) C. Moreau, C. laricicola Redfern \& Minter and C. rufipenni Wingfield, Harrington \& Solheim that are consistently vectored by Ips typographus L., Ips cembrae Heer and Dendroctonus rufipenni Kirby, respectively (Furniss et al. 1990; Harrington and Wingfield 1998; Redfern et al. 1987; Wingfield et al. 1997). Alternatively, the association of Ceratocystis species with nitidulid insects and drosophilid flies are termed "non-specific" or loose, such as in the case of C. fagacearum (Bretz) Hunt and C. fimbriata s.l. (Cease and Juzwik 2001; Moller and Devay 1968). There have been no studies regarding insect associates of Ceratocystis species in Australia although it is likely that most of these fungi on eucalypts are vectored by nitidulids and flies.

This study aimed to increase the base of knowledge pertaining to Ceratocystis species on native eucalypts in Australia. The intention is to provide an improved baseline for quarantine procedures and to predict threats of Ceratocystis disease outbreaks, globally. Wounds on eucalypt trees in the eastern part of Australia were thus investigated for the presence of 
these fungi and their nitidulid insect associates. Both morphological characteristics and multigene DNA sequence data were used to identify all fungi collected and their potential pathogenicity to eucalypt trees was investigated in greenhouse inoculation studies.

\section{Materials and Methods}

Source of samples and isolations

Collections of Ceratocystis species from Eucalyptus species and Corymbia species in Australia were made over a six-week period between March and April 2008. Because Ceratocystis species require wounds for infection, and previous studies have shown that stem wounds are commonly infected with these fungi (Kile et al. 1996; Barnes et al. 2003b; Roux et al. 2004; Kamgan Nkuekam et al. 2009). Surveys were focused on wounds resulting from harvesting as well as stem boring insects. Plantations and forests in Tasmania, New South Wales and the southern part of Queensland were visited. In Tasmania, plantations and forests near Burnie, Tarraleah and Geevestown were surveyed. In New South Wales (NSW) commercial plantations and native eucalypt forests between Sydney in the south and up to the border with Queensland were included. Some key areas sampled in NSW included Pine Creek State Forest, Wattagan State Forest, Wedding Bells State Forest, Crab-tree plantation, Ingalba State Forest and other localities around these main areas. In the state of Queensland, samples were collected from Eucalyptus trees growing around Brisbane.

Samples were collected from stumps of felled trees in all areas surveyed in Tasmania. In NSW wounds included stumps of felled trees, galleries of cossid moths (Lepidoptera: Cossidae) and cerambycid beetles (Coleoptera: Cerambycidae), as well as excavations made on the trees by parrots scavenging for larvae of insects infesting the trees. In Queensland, samples were collected from artificially induced wounds and from wounds made by birds feeding on wood-boring larvae. Pieces of bark or wood were collected from wounds and stored in separate brown paper bags for each tree, after they had been examined with a 20X magnification lens for the presence of Ceratocystis fruiting structures. All the samples were placed in separate brown paper bags for each tree or stump and transported to the laboratory in plastic bags that also served to conserve moisture and to induce sporulation. Samples from individual trees were maintained separately in brown bags and samples from each locality were grouped separately into plastic bags.

To obtain information on some of the possible insect associates of Ceratocystis species in Australia, Nitidulidae were collected from wounds on eucalypt trees bearing fungal mats. Insects were collected using an aspirator (Fergusson 1982) and transferred to separate cylindrical glass containers containing a piece of tissue paper for each tree sampled. In the laboratory, insects were inactivated by cooling the glass containers in a box containing ice. The insects were grouped according to morphological characteristics using an Axiocam stereo microscope (Carl Zeiss Ltd., Germany). Representatives of each insect group were preserved in $70 \%$ ethanol prior to identification, by Dr. Andrew Cline, Senior Insect Biosystematist, Plant Pest Diagnostics Center, California Department of Food \& Agriculture, United State of America. 
Isolation and purification of fungi from wood samples followed the same protocols described by Kamgan Nkuekam et al. (2008a). Nitidulid beetles not retained for species identification were used to determine the presence of Ceratocystis species on their bodies. This was done by squashing individual insects between two slices of carrot (Moller and Devay 1968) and incubating them for five days at $25^{\circ} \mathrm{C}$. Fungi were isolated by transferring fruiting bodies (spore masses, mycelium, ascomata) growing on the carrots to 2\% malt extract agar (MEA: $20 \mathrm{~g} / 1$ malt extract and $15 \mathrm{~g} / 1$ agar, Biolab, Midrand, South Africa and $1000 \mathrm{ml}$ sterile deionised water) containing $0.05 \mathrm{~g} / \mathrm{l}$ of streptomycin sulphate (SIGMA-ALDRICH, Steinheim, Germany).

Isolates were deposited in the culture collection (CMW) of the Forestry and Agricultural Biotechnology Institute (FABI), University of Pretoria, South Africa, and representative cultures have also been deposited with the Centraalbureau voor Schimmelcultures (CBS), Utrecht, Netherlands. Dried specimens of representative isolates were deposited in the National Collection of Fungi (PREM), Pretoria, South Africa.

Morphological characterization

Ceratocystis isolates were grouped into morphotypes, based on their morphological features in pure culture on $2 \%$ MEA. Cultures were incubated at $25^{\circ} \mathrm{C}$ until sporulation and then grouped into morphotypes based on colour (Rayner 1970) and macro-morphology. Fruiting structures including ascomata and ascospores, phialides and conidia from selected isolates representing each morphotype were mounted in $80 \%$ lactic acid on microscope slides and studied using a Zeiss Axiocam light microscope. Fifty measurements of all characteristic morphological features were made for isolates chosen as the types of new species and ten measurements were made for additional isolates. Measurements were noted as (minimum -) mean minus st. dev. - mean plus st. dev. (- maximum).

Scanning electron microscopy was used to observe conidia and conidiophores of the fungi. For this purpose, specimens were prepared following protocols described by Grobbelaar et al. (2009). Finally the specimens were critical point dried (Bio-Rad E3000, Watford, England), then mounted and coated with gold in a sputter coater and examined using a JEOL JSM-840 scanning electron microscope.

Growth in culture

One isolate of each of the purported new species found in this study was used for growth studies in culture. Disks of agar ( 9 $\mathrm{mm}$ diam.) bearing mycelium of the test isolates were transferred from the actively growing margins of seven-day-old cultures and placed upside down at the centres of $90 \mathrm{~mm}$ Petri dishes containing $2 \%$ MEA. The plates were incubated in the dark for 10 days at temperatures ranging from $5^{\circ} \mathrm{C}$ to $35^{\circ} \mathrm{C}$ at 5 degree intervals. Five replicate plates were used for each isolate at each temperature considered. Two diameter measurements, perpendicular to each other, were taken daily for each colony and the averages of ten diameter measurements for each temperature were computed (Kamgan Nukekam et al. 2008a; b). 
DNA sequence comparisons

All isolates of each morpho-group of the Ceratocystis spp. collected in this study were selected for DNA sequence comparisons. Single spore drops collected from the apices of ascomata or conidiophores in pure cultures were grown on $2 \%$ MEA for 7-10 days. Mycelium was scraped from the surface of the actively growing cultures and then transferred to $1.5 \mathrm{ml}$ Eppendorf tubes using a sterile hypodermic needle. DNA was extracted using PrepMan Ultra Sample Preparation Reagent (Applied Biosystems, Foster City, California, USA) following the manufacturer's instructions.

The internal transcribed spacer regions (ITS1, ITS2) and 5.8S gene of the ribosomal RNA operon were amplified on an Eppendorf Mastercycler (Merck, Hamburg, Germany) using primers ITS1 (3'-TCCGTAGGTGAACCTGCGG-5') and ITS4 (3'-TCCTCCGCTTATTGATATGC-5') (White et al. 1990). Part of the $\beta$-tubulin gene (BT1) and the transcription elongation factor- $1 \alpha$ gene (TEF) were also amplified using the primers $\beta$ t1 a (5'-TTCCCCCGTCTCCACTTCTTCATG-3') and $\quad \beta \mathrm{t} 1 \mathrm{~b}$ (5'-GACGAGATCGTTCATGTTGAACTC-3') (Glass and Donaldson 1995), EF1F (5'TGCGGTGGTATCGACAAGCGT-3') and EF2R (5'-AGCATGTTGTCGCCGTTGAAG-3') (Jacobs et al. 2004), respectively.

The PCR reaction mixtures as well as the thermal cycling used in this study were the same as described previously (Kamgan Nkuekam et al. 2008a). An aliquot of $5 \mu$ of the PCR products were stained with GelRed ${ }^{\mathrm{TM}}$ Nucleic Acid Gel stain (Biotium, Hayward, CA, USA), separated on a 1\% agarose gel and visualized under UV light. PCR products were purified using Sephadex G-50 Gel (Sigma-Aldrich), following the manufacturer's instructions. Subsequently, the concentrations of the purified PCR products were determined using a Nanodrop ND-1000 Spectrophotometer (Nanodrop Technologies, Rockland, USA). Sequencing reactions were performed using the Big Dye cycle sequencing kit with Amplitaq DNA polymerase, FS (Perkin-Elmer, Warrington, UK) following the manufacturer's protocol on an ABI PRISM 3100 Genetic Analyzer (Applied Biosystems). Sequencing PCRs were prepared as described by Kamgan Nkuekam et al. (2008a) and both DNA strands were sequenced.

A preliminary identity for the Ceratocystis isolates was obtained by performing a similarity search (standard nucleotide BLAST) against the GenBank database (http://www.ncbi.nlm.nih.gov). Sequences of both strands for each isolate were examined visually and combined using the programme Sequence Navigator. Sequences were then aligned automatically using Mafft ver.5.851 (Katoh et al. 2002) and analyzed using PAUP 4.0b10 (Swofford 1998). Additional sequences of related Ceratocystis species were obtained from the GenBank database. PAUP $4.0 \mathrm{~b} 10$ was used to construct phylogenetic trees from the distance matrices by pair-wise alignment of the sequences, using the maximum parsimony method (Swofford 1998). Confidence levels of the phylogenies were estimated with the bootstrap method (Felsenstein 1985).

Bayesian analyses was performed with MrBayes V3.1 (Ronquist and Heuelsenbeck 2003), based on Markov Chain Monte Carlo (MCMC) methods. The best-fit model of evolution was determined using MrModeltest V2.2 (Nylander 2004) and included for each gene partition in MrBayes. Four simultaneous MCMCs were run for 1000000 generations and trees were sampled every $100^{\text {th }}$ generation. The burn-in procedure in MrBayes V3.1 was used to discard trees that formed before the 
point of convergence, and the posterior probability in the majority rule concensus trees were calculated by MCMC sampling in MrBayes V3.1, using the best-fit model of evolution.

Pathogenicity tests

Pathogenicity tests were conducted in a quarantine greenhouse using Eucalyptus grandis clone TAG5. Five strains of each of two Ceratocystis species obtained in this study were used in the inoculation experiment. Ten trees, approximately twoyears-old ( $\sim 1 \mathrm{~cm}$ diameter), were inoculated with each test strain and five trees of the same age were inoculated with a sterile agar disc to serve as controls. Test strains included isolates (CMW28917, CMW28920, CMW28925, CMW28928, CMW28932) belonging to the C. moniliformis s.l. complex, and isolates (CMW29120, CMW29275, CMW29349, CMW29354, CMW29546) belonging to the C. fimbriata s.l. complex (Table 1). Greenhouse conditions included an average temperature of $25^{\circ} \mathrm{C}$ and natural day/night conditions of about 13 hours daylight and 11 hours darkness. Inoculations were done using the same technique as described before by Kamgan Nkuekam et al. (2008a). Six weeks (42 days) after inoculation, the lengths of lesions, including the original wound on the bark surface as well as in the cambium of each tree were measured. Results were then analyzed using the GLM procedure in SAS/STAT (SAS Institute Inc. 1999). Reisolations were made from the lesions to confirm that they had resulted from the effects of the test fungi.

\section{Results}

Source of samples and isolations

A wide variety of Ceratocystis isolates arose from collections in New South Wales, Queensland and Tasmania. Samples from which fungi were isolated were from harvesting and stem boring insect wounds on two eucalypt genera (Eucalyptus and Corymbia) spanning nine different species. These trees species included E. nitens Deane \& Maiden, E. globulus Labill, E. pilularis Sm., E. saligna Sm., E. dunnii Maiden, E. grandis Hill ex Maiden, E. grandis x camaldulensis, E. tereticornis and C. variegata (F.Muell.) K.D.Hill \& L.A.S.Johnson (Table 1). A total of 54 isolates were obtained from wounds on 200 trees sampled across the three states of Australia. Apart from discoloration of the wood around the wounds no other diseases symptoms were observed on the trees.

Nitidulidae were found only at Ingalba State forest in New South Wales. A limited number (30) of insects were collected from E. pilularis trees. These insects represented two groups based on morphology and included Brachypeplus binotatus Murray (13 insects) and Brachypeplus planus Erichson (10 insects). The remaining specimens were characteristic of Carpophilus species ( 7 insects) but could not be identified to species level. Ceratocystis spp. were isolated from four nitidulid beetles using the carrot baiting technique.

Morphological identification

Ceratocystis spp. collected in this study could broadly be assigned to three morphological groups based on colony morphology and the type of fruiting bodies produced on MEA (Table 1). Morpho-group A included species resembling 
those in the C. moniliformis s.l. species complex. This group, consisting of 18 cultures, was characterized by fast growing isolates with a strong fruity (banana) odor, ascomata exuding sticky spore drops containing hat-shaped ascospores typical of Ceratocystis species, echinulate perithecial bases and ascomatal necks having disciform bases. These isolates covered the entire surface of the $60 \mathrm{~mm}$ Petri dishes within three days at $25^{\circ} \mathrm{C}$.

Morpho-group B isolates (Table 1) included species resembling those in the C. fimbriata s.l. species complex. There were 33 isolates in this group and they were slow growing and had a granular appearance. Limited numbers of ascomata were produced in culture. These isolates had no spines on the ascomatal bases, they lacked disc-like bases on the ascomatal necks, and produced hat-shaped ascospores. Isolates in this morpho-group could be further placed in two sub-groups based on morphological characteristics. One of these sub-groups from NSW, where it was collected from both insects and trees, was lighter coloured and ascospore drops were produced abundantly. This was in contrast to isolates that originated from Eucaltyptus trees in Tasmania, and which were recognized as representing C. pirilliformis based on morphology, as described by Barnes et al. (2003b).

DNA sequence comparisons

All isolates of Ceratocystis in morpho-group A (C. moniliformis s.l.) were sequenced and selected isolates (CMW21598, CMW28917, CMW28920, CMW28925, CMW28928, CMW28932) (Table 2) including representatives from each host was used in phylogenetic analyses (Fig. 1). All isolates generated amplicons of about 600, 550 and 850 bps for the ITS, BT1 and TEF gene regions, respectively. Partition homogeneity tests using 1000 replicates for sequence data of these three gene regions resulted in a P-value of 0.283 , suggesting that the data from the three gene regions could be combined. Comparison of these isolates with those of previously published species in GenBank by analyses of the combined data sets in PAUP resulted in a total of 1130 characters including gaps, with 960 constant characters, 5 variable characters (parsimonyuninformative) and 165 parsimony informative characters.

Phylogenetic analysis using parsimony and the heuristic search options resulted in 419 best trees with a consistency index (CI) and retention index (RI) value of 0.670 and 0.892 , respectively. Isolates from Australia formed a well-resolved clade (Fig. 1), supported by a bootstrap value of $98 \%$, separate from any of the described species in the C. moniliformis s.l. species complex, suggesting that they represent an undescribed species. The closest phylogenetic neighbor of these isolates was C. moniliformis.

In separate analyses, using both parsimony and Bayesian computations across the ITS, BT1 and TEF gene regions respectively, only representatives of Morpho-group A and their most closely related phylogenetic neighbors were considered to confirm their species delimitation. In addition, the multilocus nucleotide polymorphisms showing differences among these taxa, as well as the number of fixed base pair differences across the three gene regions, were computed. In these analyses, representatives of Morpho-group A formed a well resolved clade clearly separated from its sister clades (Supplementary Material, Table 3) (Fig. 3A, 3B, 3C). This separation was supported by a number of polymorphic nucleotide sites found across the three gene regions (Supplementary Material, Table 4.1, 4.2). A number of fixed base pair 
differences were also found (Supplementary Material, Table 5, 6, 7) across the three gene regions considered and these were consistent with results based on concatenated analyses and morphology.

Isolates (CMW29120, CMW29275, CMW29354, CMW29349, CMW29546, CMW29549) in Morpho-group B1, and Morpho-group B2 (CMW29111, CMW29112, CMW29119, CMW29355) generated amplicons of about 600, 550 and 850 bps for parts of the ITS, BT1 and TEF gene regions, respectively. Partition homogeneity tests using 1000 replicates for sequence data of these three gene regions resulted in a P-value of 0.273, suggesting that the data from the three gene regions could be combined. Comparison of these isolates with those from GenBank and automatic alignment using Mafft, followed by analyses in PAUP, resulted in a total of 1289 characters including gaps, with 630 constant characters, 166 variable characters (parsimony-uninformative) and 493 parsimony informative characters. Phylogenetic analysis using parsimony and the heuristic search option resulted in 734 best trees with a consistency index (CI) and retention index (RI) value of 0.692 and 0.889 , respectively. Isolates resolved into two different clades within the larger $C$. fimbriata s.l group. Isolates representing Morpho-group B1 formed a well-resolved clade (Fig. 2), supported by a bootstrap value of 85\%, separate from any of the described species in the C. fimbriata s.l. species complex. The closest phylogenetic neighbor of these isolates was C. atrox and C. polychroma. Isolates of morphogroup B2 clustered with strains of C. pirilliformis, consistent with results based on morphological identification.

Bayesian analyses for representatives of Morpho-group B1 and Morpho-group B2 and their most closely related phylogenetic neighbors showed that representatives of morpho-group B1 formed a well resolved clade, clearly separated from its sister clades C. atrox and C. polychroma, based on the ITS, BT1 and TEF gene regions (Fig. 4A, 4B, 4C). This separation was supported by a number of fixed base pair differences found (Supplementary Material, Table 8.1, 8.2, 9, 10, 11) and these were consistent with results based on concatenated analyses. Analyses of the TEF sequence data did not provide separation between these species. Isolates in morphogroup B2 grouped with strains of $C$. pirilliformis, consistent with results based on maximum parsimony analysis (Fig. 2, 4A, 4B, 4C).

\section{Taxonomy}

Based on morphological studies and multigene sequence phylogenies, two Ceratocystis spp. from Australia emerged as distinct taxa, clearly separated from other related Ceratocystis reference strains. These included one species residing in the C. moniliformis s.l. group and one in the C. fimbriata s.l. complex. The following descriptions are provided for them.

\section{Ceratocystis tyalla Kamgan-Nkuek. \& Jol. Roux sp. nov. (Fig.5) MB519980}

Etymology: The name is derived to the aboriginal name for eucalypts in Australia.

Coloniae mellicolores in MEA in 3 diebus in $30^{\circ} \mathrm{C}$ ad $36.17 \mathrm{~mm}$ crescentes. Bases ascomatum brunneae vel nigrae, globosae vel obpyriformes, spinis indumentoque hypharum fuscis. Colla ascomatum atrobrunnea hyphis ostiolaribus divergentibus. Bases collorum basin versus ornamentis disciformibus. Asci evanescentes. Ascosporae pileiformes hyalinae non septatae, vaginis vestitae. Anamorpha Thielaviopsis conidiophoris phialidicis hyalinis tubulosis, colliculis visibilibus 
(1.5-) 2.5-6.0 (-8.5) $\mu \mathrm{m}$. Conidia hyalina non septata biformia; oblonga extremis obtusis (5.0-) 6.5-8.5 (-9.5) x (1.5-) 2.0-2.5 $(-3.0) \mu \mathrm{m}$, bacilliformiaque basibus rotundatis (8.5-) 9.0-11.0 (-12.0) x (1.5-) 2.0-2.5 (-3.5) $\mu \mathrm{m}$.

Colonies honey (19''b) coloured on MEA, reverse honey (19'’b) coloured, almost brown. Colony diameters reaching $36.17 \mathrm{~mm}$ in 3 days on $\mathrm{MEA}$ at $30^{\circ} \mathrm{C}$. Optimal growth at $30^{\circ} \mathrm{C}$, growth at $35^{\circ} \mathrm{C}$ with colony diameters reaching $33.8 \mathrm{~mm}$ in 3 days. No growth at $5^{\circ} \mathrm{C}$. Mycelium forming thick mats on agar with some white aerial mycelia. Hyphae septate, not constricted at septa. Ascomata scattered over the surface of the colonies or embedded in mycelium. Ascomatal bases brown to black, globose to obpyriform (124.5-) 143.0-175.5 (-195.5) $\mu \mathrm{m}$ long and (116.5-) 136.0-167.0 (-177.5) $\mu \mathrm{m}$ wide, with dark conical spines, (5.5-) 7.5-12.5 (-18.0) $\mu \mathrm{m}$ long and hyphal hair. Ascomatal necks dark brown (428.5-) 466.5-607.5 (-772.5) $\mu \mathrm{m}$ long, middle of necks (17.5-) 19.0-22.5 (-24.0) $\mu \mathrm{m}$ wide, tips of necks (9.0-) 11.0-13.5 (-14.5) $\mu \mathrm{m}$ wide, producing sticky and hyaline spore drops at the tips of divergent ostiolar hyphae, (14.5-) 18.0-24.5 (-28.5) $\mu \mathrm{m}$ long. Neck bases ornamented with disc-shapes, (37.0-) 43.0-52.5 (-59.5) $\mu \mathrm{m}$ wide at bases. Asci rarely seen, evanescent, deliquescing early in the development. Ascospores hat-shaped, hyaline, aseptate, invested in sheaths (3.5-) 4.0-4.5 (-5.0) x (2.0-) 2.0-2.5 (-3.0) $\mu \mathrm{m}$, accumulating in round, straw yellow (21'd) spore drops, becoming creamy with age.

Anamorph: Thielaviopsis. Conidiophores singly on mycelium, phialidic, hyaline, tubular (15.2-) 17.9-27.3 (-35.7) x (1.8-) 2-2.9 (-3.9) $\mu \mathrm{m}$; colarettes visible (1.5-) 2.5-6.0 (-8.5) $\mu \mathrm{m}$. Conidia hyaline, aseptate, two types, oblong with obtuse ends (5.0-) 6.5-8.5 (-9.5) x (1.5-) 2.0-2.5 (-3.0) $\mu \mathrm{m}$ and bacilliform with rounded bases (8.5-) 9.0-11.0 (-12.0) x (1.5-) 2.0$2.5(-3.5) \mu \mathrm{m}$. Chlamydospores (aleurioconidium) not observed.

Specimens examined: Australia, New South Wales, Marsden State Forest, isolated from cut stump of Eucalyptus dunnii, 19/03/2008, G. Kamgan Nkuekam and A. J. Carnegie, holotype PREM60434, living culture CMW28932, CBS128703

Additional specimens: Australia, New South Wales, Cairncross State Forest, isolated from E. pilularis stumps, 18/03/2008, G. Kamgan Nkuekam and A. J. Carnegie, paratype, living culture CMW28925/PREM60436/CBS127211, Wattagans State Forest, isolated from E. saligna stumps, 17/03/2008, G. Kamgan Nkuekam and A. J. Carnegie, CMW28928/PREM60435/CBS128342, Pine Creek State Forest, isolated from E. grandis stumps, 18/03/2008, G. Kamgan Nkuekam and A. J. Carnegie, CMW28917, CMW28920.

Ceratocystis corymbiicola Kamgan-Nkuek. \& Jol. Roux sp. nov. (Fig.6) MB519979.

Etymology: The name reflects the host Corymbia.

Coloniae olivaceo-bubalinae in MEA in 10 diebus in $30^{\circ} \mathrm{C}$ ad $20 \mathrm{~mm}$ crescentes. Bases ascomatum nigrae, globosae sine spinis nec ornamentis. Colla ascomatum nigra hyphis ostiolaribus divergentibus. Asci evanescentes. Ascosporae pileiformes, vaginis vestitae, non septatae. Anamorpha Thielaviopsis conidiophoris phialidicis tubulosis hyalinis, sine colliculis. Conidia biformia; bacilliformia basibus rotundatis (11.0-) 15.0-21.5 (-27.5) x (3.0-) 3.5-4.5 (-5.5) $\mu \mathrm{m}$, bacilliformiaque extremis obtusis (7.5-) 8.5-12.0 (-14.5) x (3.5-) 4.0-5.5 (-6.5) $\mu \mathrm{m}$. Chlamydosporae (aleurioconidium) ovoideae laeves singulae terminales, iuventute hyalinae, maturitate nigrescentes (8.5-) 11.0-12.0 (-16.5) x (6.5-) 8.0-11.0 (16.5) $\mu \mathrm{m}$. 
Colonies olivaceous Buff (21','d) on MEA, reverse smoke grey (21',',d). Colony diameters reaching $20 \mathrm{~mm}$ in 10 days on MEA at $30^{\circ} \mathrm{C}$. Optimal growth at $30^{\circ} \mathrm{C}$, no growth at $10^{\circ} \mathrm{C}$. Colony surfaces scattered with black ascomata. Mycelium immersed and superficial, with white-grey aerial mycelia. Hyphae septate, not constricted at septa. Ascomatal bases black, globose (159-) 189-241 (-290) $\mu \mathrm{m}$ long and (160.5-) 185.0-237.5 (-272.5) $\mu \mathrm{m}$ wide. Spines or ornamentations absent. Ascomatal necks black (603.0-) 755.0-1009.0 (-1097.5) $\mu \mathrm{m}$ long, bottom of necks smooth (43.0-) 55.0-70.5(-77.0) $\mu \mathrm{m}$ wide, middle of necks (20.0-) 27.5-34.5 (-38.5) $\mu \mathrm{m}$ wide, tips of necks (12.5-) 15.5-19.5 (-22.0) $\mu \mathrm{m}$ wide. Ostiolar hyphae present, divergent (22.5-) 42.0-58.5 (-67.5) $\mu \mathrm{m}$ long. Asci evanescent. Ascospores hat-shaped, invested in sheaths, aseptate (4.5-) 5.0-5.5 (-6.0) $\mu \mathrm{m}$ long and (2.5-) 3.0-3.5 (-4.0) $\mu \mathrm{m}$ wide. Ascospores accumulating in round or disk-shaped, Buff (19'd) colored spore drops.

Anamorph: Thielaviopsis. Conidiophores occurring singly, phialidic (17.0-) 38.5-83.0 (-109.0) x (2.0-) 3.0-5.0 (5.5) $\mu \mathrm{m}$, tubular with thin bases making them almost constricted at septa, hyaline, colarettes absent. Two types of Conidia produced; bacilliform-shaped conidia with round bases (11.0-) 15.0-21.5 (-27.5) x (3.0-) 3.5-4.5 (-5.5) $\mu \mathrm{m}$, and bacilliformshaped conidia with obtuse ends (7.5-) 8.5-12.0 (-14.5) x (3.5-) 4.0-5.5 (-6.5) $\mu \mathrm{m}$, often produced in chains. Chlamydospores (aleurioconidium) ovoid, smooth, formed singly, terminal, hyaline when young, becoming black when mature (8.5-) 11.0-12.0 (-16.5) x (6.5-) 8.0-11.0 (-16.5) $\mu \mathrm{m}$.

Specimens examined: Australia, New South Wales, Wedding Bells State Forest, isolated from cut stumps of Corymbia variegata, 19/03/2008, G. Kamgan Nkuekam and A. J. Carnegie, holotype PREM60431, living culture CMW29120/CBS127215.

Additional specimens: Australia, New South Wales, Ingalba State Forest, isolated from Brachypeplus planus infesting Eucalyptus pilularis stumps, 18/03/2008, G. Kamgan Nkuekam and A. J. Carnegie, paratype, living culture CMW29354/PREM60432/CBS127217. Isolated from E. pilularis stumps CMW29349/PREM60433/CBS127216. Wattagans State Forest, New South Wales. Isolated from E. saligna stumps, 17/03/2008, CMW29275/PREM60442, Ingalba State Forest, isolated from Carpophylus sp. infesting Eucalyptus pilularis tree, 18/03/2008, CMW29546, Dyraba State Forest, isolated from E. grandis x camaldulensis stumps, 20/03/2008, CMW29549.

Pathogenicity tests

Six weeks after inoculation, E. grandis trees were assessed for disease development based on the length of lesions on the bark or at the cambial surfaces. Ceratocystis tyalla and C. corymbiicola produced very small lesions on both the bark (Fig. 7) and the cambial surfaces (Fig. 8). Trees showed no signs of disease, and re-isolation did not yield cultures of either $C$. tyalla or C. corymbiicola. Significant differences $(\mathrm{P}<0.0001)$ in lesion lengths were, however, found between C. tyalla and C. corymbiicola when compared to the control inoculations (Fig. 7,8).

\section{Discussion}

This study reports on the most extensive survey of Ceratocystis species on eucalypts ever conducted in their country of origin. Three species of Ceratocystis were collected in Australia from either wounds on eucalypt trees or from nitidulid beetles collected from wounds on trees. Two of these are previously undescribed fungal species for which the names $C$. tyalla and C. corymbiicola have been provided. Furthermore, the host and geographic range of $C$. pirilliformis, previously 
known from Australia (Barnes et al. 2003b, Kamgan Nkuekam et al. 2009) have been expanded to include Eucalyptus trees in Tasmania.

Three Ceratocystis spp., two in the C. fimbriata s.l. species complex and one in the C. moniliformis s.l. species complex emerged from this study. These include two species described for the first time in this study and C. pirilliformis. Ceratocystis tyalla grouped in a unique sub-clade, most closely related to C. moniliformis in phylogenetic analyses. Similar to $C$. moniliformis and other fungi in the $C$. moniliformis s.l. complex, it grows rapidly in culture, produces hat-shaped ascospores and has short conical spines on the ascomatal bases. Ceratocystis tyalla could, however, be distinguished from C. moniliformis, and other related fungi, by the fact that it has a disc-like ascomatal neck base, which is less well defined than in other species of the group. Phylogenetic inference based on three gene regions also clearly distinguished this taxon from its closest relatives.

Ceratocystis corymbiicola collected from eucalypts in Australia, grouped in the C. fimbriata s.l. complex. It was most closely related to C. atrox and C. polychroma in both the combined ITS, BT and TEF data sets as well as when these gene regions were analysed separately. Bootstrap support for the unique clade containing C. corymbiicola was, however, low in the concatenated tree. Morphological differences could, however, be detected to support the description of C. corymbiicola as a unique species, distinct from C. atrox, a species also described from Australia (Van Wyk et al. 2007). C. corymbiicola produces chlamydospores structures that have not been found in C. atrox. In addition, C. corymbiicola produces two morphological forms of bacilliform conidia and only one type of phialide, while C. atrox produces cylindrical and barrelshaped conidia, and two morphologically distinct forms of phialides (Van Wyk et al. 2007). The conidia of C. corymbiicola have swellings, even when young and this feature also make the species easy to distinguish from other.

Inoculation studies with C. tyalla and C. corymbiicola under greenhouse conditions suggest that these fungi are not serious pathogens of Eucalyptus trees. Neither of them gave rise to significant lesions or any other disease symptoms of young $E$. grandis trees. This is not surprising for $C$. tyalla since species in the C. moniliformis s.l. group include only non-pathogens (Davidson 1935, Kamgan Nkuekam et al. 2008b, Van Wyk et al. 2006). Although C. corymbiicola resides in a group of Ceratocystis species known to include important plant pathogens, it appears not to have the potential to cause disease of Eucalyptus, at least under natural situation.

Both previously undescribed Ceratocystis spp. collected in this study could have much wider distributions and host ranges as found. The discovery of these fungi infecting different eucalypt genera spanning several different species suggests that eucalypts are probably their primary hosts. Furthermore, isolating C. corymbiicola from nitidulid beetles suggests that these insects could be potential vectors of the fungus in Australia, similar to what is known for these fungi from other continents.

It was not surprising to find $C$. pirilliformis infecting wounds of Eucalyptus trees in Australia. This fungus was first described from wounds on E. nitens in Australia (Barnes et al. 2003b) and has subsequently also been found on Eucalyptus species in South Africa (Roux et al. 2004; Kamgan Nkuekam et al. 2009). Results of this study expand the host and geographic range of $C$. pirilliformis. It is suspected that the fungus is native to Australia, based on its wide distribution (Tasmania to Queensland) in the country and the fact that it appears not to cause disease on eucalypts (Barnes et al. 2003b; 
Kamgan Nkuekam et al. 2009). A recent population diversity study of $C$. pirilliformis collected in South Africa showed a low level of diversity for isolates in South Africa and suggested high population diversity for the few isolates available from Australia (Kamgan Nkuekam et al. 2009). However, larger populations of C. pirilliformis from Australia are required to fully elucidate the origin of this fungus.

Brachypeplus binotatus and B. planus, the two nitidulid species identified in this study in association with Ceratocystis species, have been reported from Australia previously. Numerous other species of Nitidulidae including Carpophilus species are also known to occur in Australia in various localities and habitats (Masters 2009). However, nitidulid beetles have not previously been found in association with Ceratocystis species in Australia. The results suggest that these insects are probably involved in overland spread of these fungi and further study of this association is likely to yield interesting insights into the biology of Ceratocystis species and their vectors in that country.

\section{Acknowledgements}

We thank the DST/NRF Center of Excellence in Tree Health Biotechnology (CTHB), National Research Foundation of South Africa (NRF), the THRIP Initiative of the Department of Trade and Industry (THRIP/DST), members of the Tree Protection Co-operative Programme (TPCP) and the University of Pretoria for funding and the facilities to undertake this study. We are also most grateful to the CSIRO Division of Forestry in Hobart (Tasmania), the New South Wales Department of Primary Industry and Fisheries in Sydney and the Queensland Department of Primary Industry and Fisheries in Brisbane for hosting G. Kamgan Nkuekam and providing the opportunity to collect specimens in Australia. Prof. Goeneveld and Dr. Van der Linde from the Department of Statistics are thanked for their assistance with the statistical analyses. Dr. Andrew Cline from the USA is thanked for identifying insects collected in this study. We further thank Dr. Hugh Glen who provided the Latin diagnosis and suggested the names for the new taxa. 


\section{References}

Barnes I, O’Neill M, Roux J, Wingfield BD, Wingfield ML (2003a) Ceratocystis fimbriata infecting Eucalyptus grandis in Uruguay. Australas Plant Path 32: 361-366.

Barnes I, Roux J, Wingfield BD, Dudzinski MJ, Old KM, Wingfield MJ (2003b) Ceratocystis pirilliformis, a new species from Eucalyptus nitens in Australia. Mycologia 95: 865-871.

Carnegie AJ, Burgess T, Beilharz V, Wingfield MJ (2007) New species of Mycosphaerella from Myrtaceae in plantations and native forests in New South Wales, Australia. Mycologia 99: 461-474.

Cease KR, Juzwik J (2001) Predominant nitidulid species (Coleoptera: Nitidulidae) associated with spring oak wilt mats in Minnesota. Can J Forest Res 31: 635-643.

Davidson RW (1935) Fungus causing stain in logs and lumber in the southern states, including five new species. J Agric Res 50: 789-807.

Felsenstein J (1985) Confidence limits on phylogenies: an approach using the bootstrap. Evolution 39: 783-791.

Fergusson NDM (1982) Pooter post. Antenna 6: 282-284.

Fouche N, Roux J, Solheim H, Heath RN, Kamgan Nkuekam G, Chimwamurumbe P, Kegg KG, Wingfield MJ (2007) Identification of Ceratocystis species isolated from hardwood trees in Namibia, Australia and Norway. 45th Congress of the Southern African Society for Plant Pathology. 21- 24 January 2007, Kopanong Conference Centre, Benoni, South Africa.

Furniss MM, Christiansen E, Solheim H (1990) Transmission of blue stain fungi by Ips typographus (Coleoptera: Scolytidae) in Norway spruce. Ann Entomol Soc Am 83: 712-716.

Glass NL, Donaldson GC (1995) Development of primer sets designed for use with the PCR to amplify conserved genes from filamentous Ascomycetes. Appl Environ Microb 61: 1323-1330.

Grobbelaar J, Aghayeva D, De Beer ZW, Bloomer P, Wingfield M, Wingfield B (2009) Delimitation of Ophiostoma quercus and its synonyms using multiple gene phylogenies. Mycol Prog 8: 221-236.

Halsted BD (1890) Some fungus diseases of the sweet potato. The black rot. N J Agr Exp Sta Bull 76: 7-14.

Halsted BD, Fairchild DG (1891) Sweet potato black rot. Journal of Mycology 7: 1-11.

Harrington TC, Wingfield MJ (1998) The Ceratocystis species on conifers. Can J Botany 76: 1446-1457.

Hill KD, Johnson LAS (1995) Systematic studies in the eucalypts 7. a revision of the bloodwoods, genus Corymbia (Myrtaceae). Tolepea 6: 185-504.

Iglesias-Trabado G, Wilstermann D (2008) Eucalyptus universalis. Global cultivated eucalypt forests map 2008. Version 1.0.1. In: 'GIT Forestry Consulting's EUCALYPTOLOGICS'. Available at www.git-forestry.com

Jacobs K, Bergdahl DR, Wingfield MJ, Halik S, Seifert KA, Bright DE, Wingfield BD (2004) Leptographium wingfieldii introduced into North America and found associated with exotic Tomicus piniperda and native bark beetles. Mycol Res 108: 411-418.

Kamgan Nkuekam G, Barnes I, Wingfield MJ, Roux J (2009) Distribution and population diversity of Ceratocystis pirilliformis in South Africa. Mycologia 101: 17-25.

Kamgan Nkuekam G, Jacobs K, de Beer ZW, Wingfield MJ, Roux J (2008a) Pesotum australi sp. nov. and Ophiostoma quercus associated with Acacia mearnsii trees in Australia and Uganda. Australas Plant Path 37: 406-416.

Kamgan Nkuekam G, Jacobs K, De Beer ZW, Wingfield MJ, Roux J (2008b) Ceratocystis and Ophiostoma species, including three new taxa, associated with wounds on native South African trees. Fungal Divers 29: 37-59. 
Katoh K, Misawa K, Kuma KI, Miyata T (2002) MAFFT: a novel method for rapid sequence alignment based on fast Fourier transform. Nucleic Acids Res 30: 3059-3066.

Keane PJ, Kile GA, Podger FD, Brown BN (2000) Diseases and Pathogens of eucalypts. CSIRO Publishing, Melbourne.

Kile GA (1993) Plant diseases caused by species of Ceratocystis sensu stricto and chalara. In: Wingfield MJ, Seifert KA, Webber JF (eds.). Ceratocystis and Ophiostoma: Taxonomy, Ecology and Pathogenicity. American Phytopathological Society Press, St. Paul, Minnesota. Pp. 173-183.

Kile GA, Dudzinski MJ, Harrington TC, Old KM, Yuan ZQ (1996) Ceratocystis eucalypti sp. nov., a vascular stain fungus from eucalyps in Australia. Mycol Res 100: 571-579.

Masters G (2009) Catalogue of the described Coleoptera of Australia. BiblioLife, Sydney, Australia.

Moller WJ, Devay JE, 1968. Insect transmission of Ceratocystis fimbriata in deciduous fruit orchards. Phytopathology 58: 1499-1507.

Morris MJ, Wingfield MJ, De Beer C (1993) Gummosis and wilt of Acacia mearnsii in South Africa caused by Ceratocystis fimbriata. Plant Patholol 42: 814-817.

Nylander JAA (2004) MrModeltest v2. Program distributed by the author. Evolutionary Biology Centre, Uppsala University.

Park RF, Keane PJ, Wingfield MJ, Crous PW (2000) Fungal diseases of eucalypt foliage. In: Keane PJ, Kile GA, Podger FD, Brown BN, (eds). Diseases and Pathogens of eucalypts. Pp.153-240. CSIRO Publishing, Melbourne.

Rayner RW (1970) A mycological colour chart. Commonwealth Mycological Institute and British Mycological Society, Kew, Surrey.

Redfern BD, Minter DW, Stoakley JT, Steele H (1987) Dieback and death of larch caused by Ceratocystis laricicola $\mathrm{sp.}$ nov. following attack by Ips cembrae. Plant Pathol 36: 467-480.

Ronquist F, Heuelsenbeck JP (2003) MrBayes: Bayesian phylogenetic inference under mixed models. Bioinformatics 19: 1572-1574.

Roux J, Alfenas AC, Bouillet JP, Wingfield MJ, Wingfield BD (1999) A serious new wilt disease of Eucalyptus caused by Ceratocystis fimbriata in Central Africa. Forest Pathol 30: 175-184.

Roux J, Bouillet JP, Coutinho TA, Wingfield MJ (2000) Diseases of plantations Eucalyptus in the Republic of Congo. S Afr J Sci 96: 454-456.

Roux J, Coutinho TA, Mujuni BD, Wingfield MJ (2001) Diseases of plantation Eucalyptus in Uganda. S Afr J Sci 97: 1618.

Roux J, Van Wyk M, Hatting H, Wingfield MJ (2004) Ceratocystis species infecting stem wounds on Eucalyptus grandis in South Africa. Plant Pathol 53: 414-421.

Roux J, Wingfield MJ (2009) Ceratocystis species: emerging pathogens of non-native plantation Eucalyptus and Acacia species. South Forests 72: 115-120.

SAS Institute Inc., SAS/STAT Users Guide, Version 8, Cary NC: SAS Institute Inc., 1999. ISBN 1-58025-494-2.

Swofford DL (1998) PAUP. Phylogenetic analysis using parsimony (and other methods). Version 4. Sinaur Associates, Sunderland, Massachusetts.

Tarigan M, Roux J, Van Wyk M, Tjahjono B, Wingfield MJ (2010) A new wilt and die-back disease of Acacia mangium associated with Ceratocystis manginecans and C. acaciivora sp. nov. in Indonesia. S Afr J Bot (in press). 
Van Wyk M, Barnes I, Roux J, Wingfield BD, Wingfield MJ. (2006) Molecular phylogeny of the Ceratocystis moniliformis complex and description of C. tribiliformis sp. nov. Fungal Diver 21: 181-201.

Van Wyk M, Pegg G, Lawson S, Wingfield MJ (2007) Ceratocystis atrox sp. nov associated with Phoracanthta acanthocera infestations on Eucalyptus grandis in Australia. Australas Plant Path 36: 407-414.

White TJ, Bruns T, Lee S, Taylor J (1990) Amplification and direct sequencing of fungal ribosomal RNA genes for phylogenetics. In: Innis MA, Gelfand DH, Sninsky JJ, White TJ (eds.), 'PCR Protocols: A sequencing guide to methods and applications'. Academic Press, San Diego. Pp. 315-322.

Wingfield MJ (2003) Increasing threat of diseases to exotic plantation forests in the Southern Hemisphere: Lessons from Cryphonectria canker. Australas Plant Path 32: 133-139.

Wingfield MJ, De Beer C, Visser C, Wingfield BD (1996) A new Ceratocystis species defined using morphological and ribosomal DNA sequence comparisons. Syst Appl Microbiol 19: 191-202.

Wingfield MJ, Harrington TC, Solheim H (1997) Two species in the Ceratocystis coerulescens complex from conifers in western North America. Can J Botany 75: 827-834.

Wingfield MJ, Slippers B, Hurley BP, Coutinho TA, Wingfield BD, Roux J (2008) Eucalypt pests and diseases: growing threats to plantation productivity. South Forests 70: 139-144

Yuan Zi-Qing, Mohammed C (2002) Ceratocystis moniliformopsis sp. nov., an early coloniser of Eucalyptus oblique logs in Tasmania, Australia. Aust Syst Bot 15: 125-133. 
Table 1 List of Ceratocystis isolates and their morphogroups collected during surveys in Eastern and Southern Australia.

\begin{tabular}{|c|c|c|c|c|c|c|c|}
\hline Morphogroups & States & Area & Hosts & $\begin{array}{l}\text { Isolate } \\
\text { Number }\end{array}$ & Fungal species & Coordinates & Collectors \\
\hline \multirow[t]{6}{*}{$\overline{\mathrm{A}}$} & NSW & $\begin{array}{l}\text { Marsden } \\
\text { State Forest }\end{array}$ & $\begin{array}{l}\text { E. dunnii } \\
\text { stumps }\end{array}$ & $\begin{array}{l}28930, \\
28931, \\
28932,28933\end{array}$ & C. tyalla & $\begin{array}{l}\mathrm{S} 30^{\circ} 14, \\
503^{\prime} \\
\mathrm{E} 152^{\circ} 38, \\
745^{\prime}\end{array}$ & $\begin{array}{l}\text { G.NK. } \\
\text { Kamgan \& } \\
\text { A.J. Carnegie }\end{array}$ \\
\hline & “ & $\begin{array}{l}\text { Wattagans } \\
\text { State Forest }\end{array}$ & $\begin{array}{l}\text { E. saligna } \\
\text { stumps }\end{array}$ & $\begin{array}{l}28927 \\
28928,28929\end{array}$ & “ & $\begin{array}{l}\mathrm{S} 33^{\circ} 02, \\
738^{\prime} \\
\mathrm{E} 151^{\circ} 19, \\
402^{\prime}\end{array}$ & “ \\
\hline & “ & $\begin{array}{l}\text { Cairncross } \\
\text { State Forest }\end{array}$ & $\begin{array}{l}\text { E. pilularis } \\
\text { trees }\end{array}$ & $\begin{array}{l}28923, \\
28924, \\
28925,28926\end{array}$ & “ & $\begin{array}{l}\mathrm{S} 31^{\circ} 21, \\
275^{\circ} \\
\mathrm{E} 152^{\circ} 45, \\
671^{\circ}\end{array}$ & “ \\
\hline & “ & $\begin{array}{l}\text { Pine Creek } \\
\text { State Forest }\end{array}$ & $\begin{array}{l}\text { E. grandis } \\
\text { stumps }\end{array}$ & $\begin{array}{l}28920 \\
28921,28922\end{array}$ & 6 & $\begin{array}{l}\mathrm{S} 31^{\circ} 21, \\
361^{\prime} \\
\mathrm{E} 152^{\circ} 45, \\
009^{\prime}\end{array}$ & “ \\
\hline & “ & $\begin{array}{l}\text { Pine Creek } \\
\text { State Forest }\end{array}$ & $\begin{array}{l}\text { E. grandis } \\
\text { stumps }\end{array}$ & $\begin{array}{l}28917 \\
28918,28919\end{array}$ & “ & $\begin{array}{l}\mathrm{S} 30^{\circ} 23, \\
545^{\prime} \\
\mathrm{E} 152^{\circ} 56, \\
975^{\prime}\end{array}$ & 6 \\
\hline & QLD & Brisbane & E. tereticornis & 21598 & 6 & NA & $\begin{array}{l}\text { J. Roux \& } \\
\text { G.S. Pegg }\end{array}$ \\
\hline \multirow[t]{3}{*}{ B1 } & QLD & Brisbane & E. tereticornis & $\begin{array}{l}21599, \\
21600, \\
21601,21602\end{array}$ & C. corymbiicola & NA & “ \\
\hline & NSW & $\begin{array}{l}\text { Wedding } \\
\text { bells State } \\
\text { Forest }\end{array}$ & C. variegata & $\begin{array}{l}29120, \\
29121, \\
29122, \\
29123, \\
29124, \\
29347, \\
29348,29428\end{array}$ & “ & $\begin{array}{l}\mathrm{S} 30^{\circ} 03 \\
498^{\prime} \\
\mathrm{E} 153^{\circ} 10 \\
266^{\prime}\end{array}$ & $\begin{array}{l}\text { G.NK. } \\
\text { Kamgan \& } \\
\text { A.J. Carnegie }\end{array}$ \\
\hline & “ & $\begin{array}{l}\text { Wattagans } \\
\text { State Forest }\end{array}$ & E. saligna & $\begin{array}{l}29275, \\
29276,29434\end{array}$ & “ & $\begin{array}{l}\mathrm{S} 33^{\circ} 02, \\
738^{\prime} \\
\mathrm{E} 151^{\circ} 19\end{array}$ & “ \\
\hline
\end{tabular}


402 '

“

$\mathrm{S} 28^{\circ} 48$

6

State Forest camaldulensis

522 '

trees

$\mathrm{E} 152^{\circ} 50$,

$370^{\prime}$

“ Nabiac

E. grandis 29344,

“

$\mathrm{S} 32^{\circ} 05$,

“

trees 29345, 29346

$411^{\prime}$

$\mathrm{E} 152^{\circ} 21$,

$838^{\prime}$

“ $\quad$ KEW

E. grandis $x$

29547

6

$\mathrm{S} 31^{\circ} 36$,

camaldulensis

954'

trees

$\mathrm{E} 152^{\circ} 44$,

096'

“ Ingalba

E. pilularis

29349

“6

$\mathrm{S} 30^{\circ} 47$,

State Forest stumps

970 '

$\mathrm{E} 152^{\circ} 51$,

706 '

4

Carpophilus

29353, 29546

“

$\mathrm{S} 30^{\circ} 47$,

970'

State Forest sp. infesting

E. pilularis

tree

“

Brachypeplus

29354

State Forest planus

infesting $E$.

pilularis tree

B2

\begin{tabular}{|c|c|c|c|}
\hline NSW & $\begin{array}{l}\text { Crab tree } \\
\text { plantation }\end{array}$ & $\begin{array}{l}\text { E. grandis } \\
\text { trees, infested } \\
\text { by giant wood } \\
\text { moths and } \\
\text { damaged by } \\
\text { cocketou bird }\end{array}$ & 29355 \\
\hline Tasmania & Burnie & $\begin{array}{l}\text { E. nitens } \\
\text { stumps }\end{array}$ & $\begin{array}{l}29111, \\
29112, \\
29113,29114\end{array}$ \\
\hline " & Burnie & $\begin{array}{l}\text { E. globulus } \\
\text { stumps }\end{array}$ & 29119 \\
\hline
\end{tabular}

C. pirilliformis

$\mathrm{E} 152^{\circ} 51$,

706 '

“ $\mathrm{S} 30^{\circ} 47$,

970'

$\mathrm{E} 152^{\circ} 51$,

$706^{\prime}$

$\mathrm{S} 30^{\circ} 08$,

345 ,

$\mathrm{E} 153^{\circ} 06$,

123

“

$“$

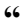

$\begin{array}{lll} & \mathrm{S} 41^{\circ} 10, & \text { G.NK. } \\ 185^{\prime} & \text { Kamgan \& } \\ \mathrm{E} 145^{\circ} 45, & \text { Caroline } \\ 441^{\prime} & \text { Mohammed } \\ & \mathrm{S} 41^{\circ} 08, & \text { “ } \\ 783^{\prime} & \\ \mathrm{E} 145^{\circ} 48, & \end{array}$


“ Tarraleah

$\begin{array}{ll}\text { E. nitens } & 29092, \\ \text { stumps } & 29093,29094\end{array}$

“

$\mathrm{S} 11^{\circ} 15$,

66

846'

E024 19 ,

$115^{\prime}$ 
Table 2 List of Ceratocystis isolates and their GenBank accession numbers sequenced in this study $(*)$ or used for DNA sequence comparisons.

\begin{tabular}{|c|c|c|c|c|c|c|c|}
\hline $\begin{array}{l}\text { Isolates } \\
\text { designation }\end{array}$ & $\begin{array}{l}\text { Isolate } \\
\text { number }\end{array}$ & Genbank & $\begin{array}{l}\text { Gene } \\
\text { regions }\end{array}$ & Other numbers & Hosts & Collectors & Origin \\
\hline \multirow[t]{6}{*}{ C. acaciivora } & CMW22562 & EU588655 & ITS & $\overline{\mathrm{NA}}$ & Acacia mangium & M. Tarigan & Indonesia \\
\hline & & EU588635 & BT & “ & “ & “ & “ \\
\hline & & EU588645 & $\mathrm{EF}$ & “ & “ & “ & “ \\
\hline & CMW22563 & EU588656 & ITS & NA & “ & “ & “ \\
\hline & & EU588636 & BT & “ & “ & “ & “ \\
\hline & & EU588646 & $\mathrm{EF}$ & “ & “ & “ & “ \\
\hline \multirow[t]{6}{*}{ C. albifundus } & CMW4068 & DQ520638 & ITS & NA & Acacia mearnsii & J. Roux & South Africa \\
\hline & & EF070429 & BT & “ & “ & “ & “ \\
\hline & & EF070400 & $\mathrm{EF}$ & “ & “ & “ & “ \\
\hline & CMW5329 & AF388947 & ITS & NA & A. mearnsii & J. Roux & Uganda \\
\hline & & DQ371649 & $\mathrm{BT}$ & “ & “ & “ & “ \\
\hline & & EF070401 & $\mathrm{EF}$ & “ & “" & “ & “ \\
\hline \multirow[t]{6}{*}{ C. atrox } & CMW19383 & EF070414 & ITS & CBS120517 & E. grandis & M.J. Wingfield & Australia \\
\hline & & EF070430 & BT & “ & “ & “ & “ \\
\hline & & EF070402 & $\mathrm{EF}$ & “ & “ & “ & “ \\
\hline & CMW19385 & EF070415 & ITS & CBS120518 & E. grandis & M.J. Wingfield & Australia \\
\hline & & EF070431 & $\mathrm{BT}$ & “ & “" & “ & “ \\
\hline & & EF070403 & $\mathrm{EF}$ & “ & “ & “ & “ \\
\hline \multirow[t]{6}{*}{ C. bhutanensis } & CMW8399 & AY528959 & ITS & $\begin{array}{l}\text { CBS115772, } \\
\text { BH } 8 / 8\end{array}$ & Picea spinulosa & $\begin{array}{l}\text { T. Kirisits \& D.B. } \\
\text { Chhetri }\end{array}$ & Bhutan \\
\hline & & AY528964 & $\mathrm{BT}$ & “ & “ & “ & “ \\
\hline & & AY528954 & $\mathrm{EF}$ & “ & “ & “ & “ \\
\hline & CMW8215 & AY528958 & ITS & $\begin{array}{l}\text { CBS114290, } \\
\text { PREM57805 }\end{array}$ & P. spinulosa & $\begin{array}{l}\text { T. Kirisits \& D.B. } \\
\text { Chhetri }\end{array}$ & Bhutan \\
\hline & & AY528963 & BT & “ & “" & “ & “ \\
\hline & & AY528953 & $\mathrm{EF}$ & “ & “ & “ & “ \\
\hline \multirow[t]{6}{*}{ C. caryae } & CMW14793 & EF070424 & ITS & CBS114716 & $\begin{array}{l}\text { Carya } \\
\text { cordiformis }\end{array}$ & J. Johnson & USA \\
\hline & & EF070439 & BT & “ & “" & “ & “ \\
\hline & & EF070412 & $\mathrm{EF}$ & “ & “" & “ & “ \\
\hline & CMW14808 & EF070423 & ITS & CBS115168 & C. ovata & “ & USA \\
\hline & & EF070440 & $\mathrm{BT}$ & “ & “ & “ & “ \\
\hline & & EF070411 & $\mathrm{EF}$ & “ & “ & “ & “ \\
\hline C. colombiana & CMW5751 & AY177233 & ITS & CBS121792 & Coffea arabica & M. Marin & Colombia \\
\hline
\end{tabular}




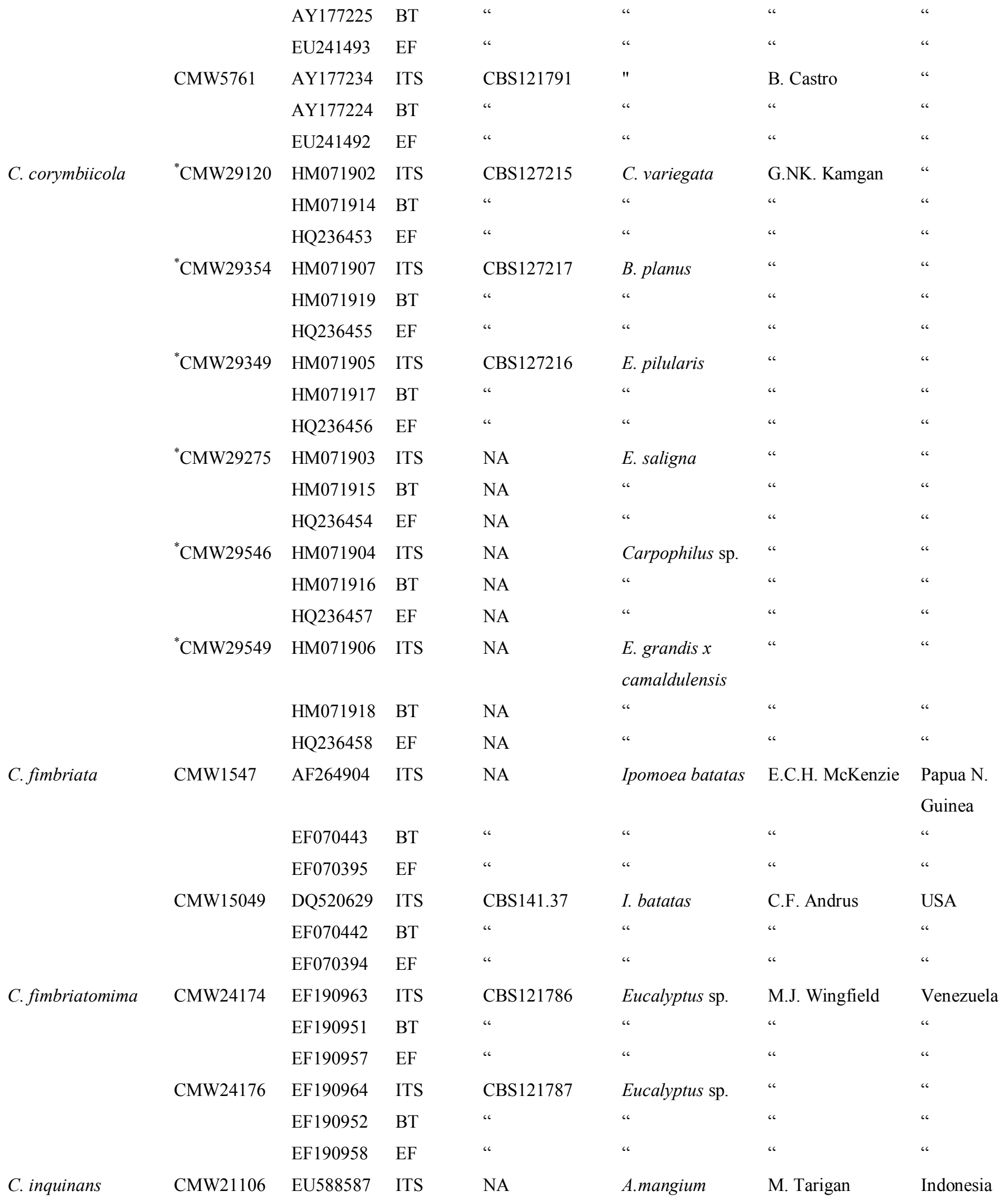




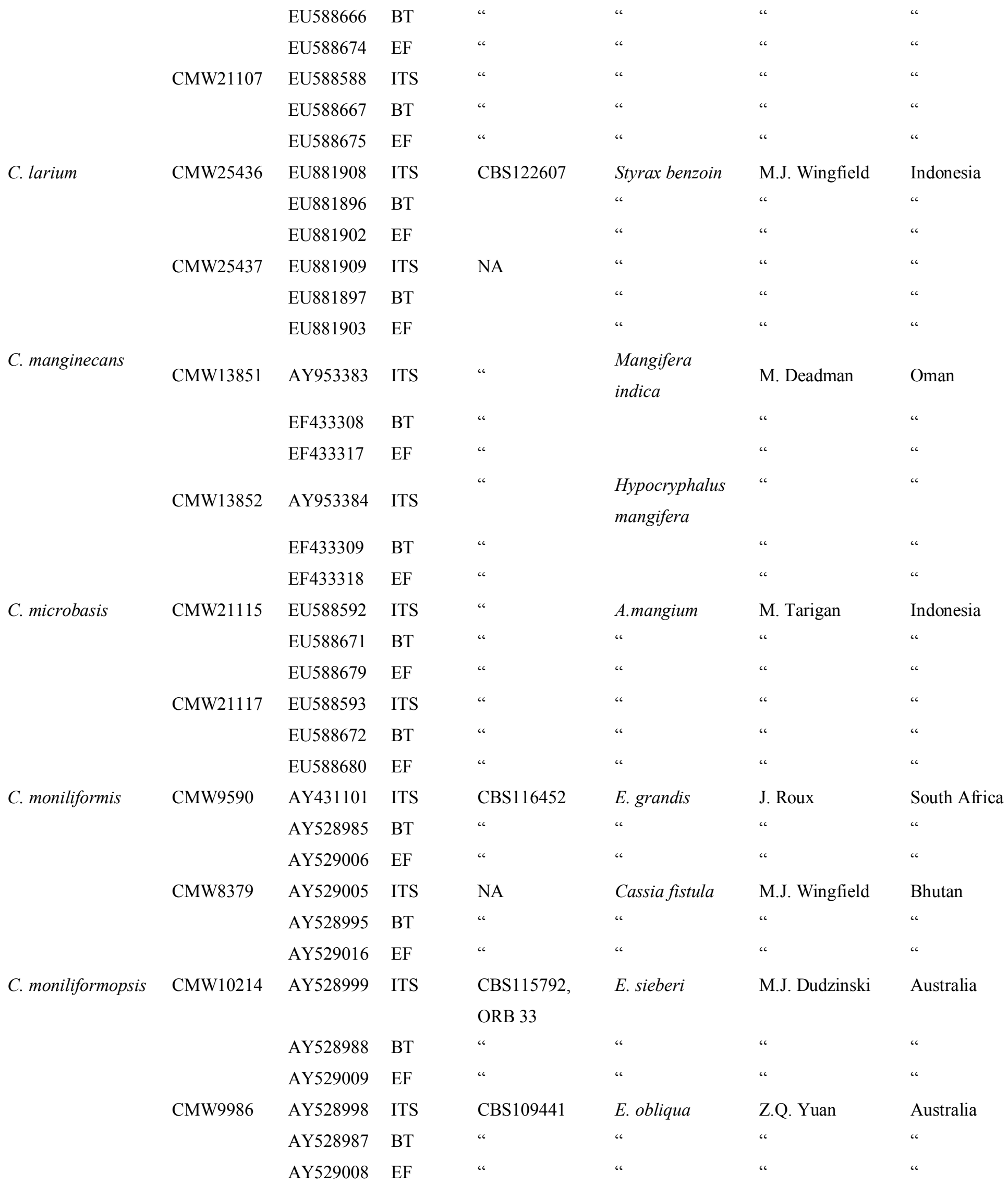




\begin{tabular}{|c|c|c|c|c|c|c|c|}
\hline \multirow[t]{6}{*}{ C. neglecta } & CMW17808 & EF127990 & ITS & CBS121789 & Eucalyptus sp. & M.J. Wingfield & Colombia \\
\hline & & EU881898 & $\mathrm{BT}$ & & & “ & “ \\
\hline & & EU881904 & $\mathrm{EF}$ & & & “ & “ \\
\hline & CMW18194 & EF127991 & ITS & CBS121017 & Eucalyptus sp. & “ & “ \\
\hline & & EU881899 & $\mathrm{BT}$ & & & “ & “ \\
\hline & & EU881905 & $\mathrm{EF}$ & & & “ & “ \\
\hline \multirow[t]{6}{*}{ C. oblonga } & CMW23802 & EU245020 & ITS & CBS122820 & A. mearnsii & R.N. Heath & South Africa \\
\hline & & EU244992 & $\mathrm{BT}$ & “ & “ & “ & “ \\
\hline & & EU244952 & $\mathrm{EF}$ & “ & “ & “ & “ \\
\hline & CMW23803 & EU245019 & ITS & CBS122291 & A. mearnsii & R.N. Heath & South Africa \\
\hline & & EU244991 & $\mathrm{BT}$ & “ & “ & “ & “ \\
\hline & & EU244951 & $\mathrm{EF}$ & “ & “" & “ & “ \\
\hline \multirow[t]{6}{*}{ C. obpyriformis } & CMW23807 & EU245004 & ITS & CBS122608 & A. mearnsii & R.N. Heath & South Africa \\
\hline & & EU244976 & BT & “ & “ & “ & “ \\
\hline & & EU244936 & $\mathrm{EF}$ & “ & “ & “ & “ \\
\hline & CMW23808 & EU245003 & ITS & CBS122511 & “" & “ & “ \\
\hline & & EU244975 & $\mathrm{BT}$ & “ & “ & “ & “ \\
\hline & & EU244935 & $\mathrm{EF}$ & “ & “ & “ & “ \\
\hline \multirow[t]{6}{*}{ C. omanensis } & CMW11048 & DQ074742 & ITS & $\begin{array}{l}\text { CBS115780, } \\
\text { PREM57815 }\end{array}$ & $\begin{array}{l}\text { Mangifera } \\
\text { indica }\end{array}$ & AO. Al-Adawi & Oman \\
\hline & & DQ074732 & $\mathrm{BT}$ & “ & “ & “ & “ \\
\hline & & DQ074737 & $\mathrm{EF}$ & “ & “ & “ & “ \\
\hline & CMW11046 & DQ074739 & ITS & $\begin{array}{l}\text { CBS118112, } \\
\text { PREM57814 }\end{array}$ & M. indica & AO. Al-Adawi & Oman \\
\hline & & DQ074729 & $\mathrm{BT}$ & “ & “ & “ & “ \\
\hline & & DQ074734 & $\mathrm{EF}$ & “ & “ & “" & “ \\
\hline \multirow[t]{6}{*}{ C. papillata } & CMW8850 & AY233866 & ITS & CBS121794 & Citrus $x$ tangelo & M.J. Wingfield & Colombia \\
\hline & & AY233875 & BT & & & “ & “ \\
\hline & & EU241485 & $\mathrm{EF}$ & & & “ & “ \\
\hline & CMW8856 & AY233867 & ITS & CBS121793 & Citrus lemon & “ & “ \\
\hline & & AY233874 & BT & & & “ & “ \\
\hline & & EU241484 & $\mathrm{EF}$ & & & “ & “ \\
\hline \multirow[t]{4}{*}{ C. pirilliformis } & CMW6569 & AF427104 & ITS & $\begin{array}{l}\text { PREM57322, } \\
\text { DAR75993 }\end{array}$ & E. nitens & M.J. Wingfield & Australia \\
\hline & & DQ371652 & BT & “ & “ & “" & “ \\
\hline & & AY528982 & $\mathrm{EF}$ & “ & “ & “ & “ \\
\hline & CMW6579 & AF427105 & ITS & $\begin{array}{l}\text { PREM57323, } \\
\text { DAR75996 }\end{array}$ & E. nitens & M.J. Wingfield & Australia \\
\hline
\end{tabular}




\begin{tabular}{|c|c|c|c|c|c|c|c|}
\hline & & DQ371653 & BT & “ & “ & “ & “ \\
\hline & & AY528983 & $\mathrm{EF}$ & “ & “ & “ & “ \\
\hline & ${ }^{*} \mathrm{CMW} 29111$ & NA & ITS & NA & E. nitens & G.NK. Kamgan & “ \\
\hline & & NA & BT & NA & “ & “ & “ \\
\hline & & NA & $\mathrm{EF}$ & NA & “ & “ & “ \\
\hline & *CMW29112 & NA & ITS & NA & E. nitens & “ & “ \\
\hline & & NA & BT & NA & “ & “ & “ \\
\hline & & NA & $\mathrm{EF}$ & NA & “ & “ & “ \\
\hline & ${ }^{*} \mathrm{CMW} 29119$ & NA & ITS & NA & E. globulus & “ & “ \\
\hline & & NA & BT & NA & “ & “ & “ \\
\hline & & NA & $\mathrm{EF}$ & NA & “ & “ & “ \\
\hline & ${ }^{*}$ CMW29355 & NA & ITS & NA & E. grandis & “ & “ \\
\hline & & NA & $\mathrm{BT}$ & NA & “ & “ & “ \\
\hline & & NA & $\mathrm{EF}$ & NA & “" & “ & “ \\
\hline C. platani & CMW14802 & DQ520630 & ITS & CBS115162 & $\begin{array}{l}\text { Platanus } \\
\text { occidentalis }\end{array}$ & T.C. Harrington & USA \\
\hline & & EF070425 & BT & “ & “ & “ & “ \\
\hline & & EF070396 & $\mathrm{EF}$ & “ & “ & “ & “ \\
\hline & CMW23918 & EU426554 & ITS & NA & “ & M.J. Wingfield & Greece \\
\hline & & EU426555 & BT & “ & “ & “ & “ \\
\hline & & EU426556 & $\mathrm{EF}$ & “ & “ & “ & “ \\
\hline C. polychroma & CMW11424 & AY528970 & ITS & $\begin{array}{l}\text { CBS115778, } \\
\text { PREM57818 }\end{array}$ & $\begin{array}{l}\text { Syzygium } \\
\text { aromaticum }\end{array}$ & $\begin{array}{l}\text { E.C.Y. Liew \& } \\
\text { M.J. Wingfield }\end{array}$ & Indonesia \\
\hline & & AY528966 & BT & “ & “ & “ & “ \\
\hline & & AY528978 & $\mathrm{EF}$ & “ & “ & “ & “ \\
\hline & CMW11436 & AY528971 & ITS & $\begin{array}{l}\text { CBS115777, } \\
\text { PREM57819 }\end{array}$ & S. aromaticum & $\begin{array}{l}\text { E.C.Y. Liew \& } \\
\text { M.J. Wingfield }\end{array}$ & Indonesia \\
\hline & & AY528967 & BT & “ & “ & “ & “ \\
\hline & & AY528979 & $\mathrm{EF}$ & “ & “ & “ & “ \\
\hline C. polyconidia & CMW23809 & EU245006 & ITS & CBS122289 & A. mearnsii & R.N. Heath & South Africa \\
\hline & & EU244978 & BT & “ & “ & “ & “ \\
\hline & & EU244938 & $\mathrm{EF}$ & “ & “ & “ & “ \\
\hline & CMW23818 & EU245007 & ITS & CBS122290 & “ & “ & “ \\
\hline & & EU244979 & $\mathrm{BT}$ & “ & “ & “ & “ \\
\hline & & EU244939 & $\mathrm{EF}$ & “ & “ & “ & “ \\
\hline C. populicola & CMW14789 & EF070418 & ITS & CBS119.78 & Populus sp. & J. Gremmen & Poland \\
\hline & & EF070434 & BT & “ & “ & “ & “ \\
\hline & & EF070406 & $\mathrm{EF}$ & “ & “ & “ & “ \\
\hline
\end{tabular}




\begin{tabular}{|c|c|c|c|c|c|c|c|}
\hline & CMW14819 & EF070419 & ITS & CBS114725 & Populus sp. & T. Hinds & USA \\
\hline & & EF070435 & BT & “ & “ & “ & “ \\
\hline & & EF070407 & $\mathrm{EF}$ & “ & “ & “ & “ \\
\hline \multirow[t]{8}{*}{ C. savannae } & CMW17300 & EF408551 & ITS & CBS121151 & Acacia & G.NK. Kamgan & South Africa \\
\hline & & & & & nigrescens & \& J. Roux & \\
\hline & & EF408565 & $\mathrm{BT}$ & “ & “ & ، & “ \\
\hline & & EF408572 & $\mathrm{EF}$ & “ & “ & “ & “ \\
\hline & CMW17297 & EF408552 & ITS & CBS121021 & Combretum & G.NK. Kamgan & South Africa \\
\hline & & & & & zeyheri & \& J. Roux & \\
\hline & & EF408566 & BT & “ & “ & “ & “ \\
\hline & & EF408573 & $\mathrm{EF}$ & “ & “ & “ & “ \\
\hline \multirow[t]{4}{*}{ C. smalleyi } & CMW14800 & EF070420 & ITS & CBS114724 & Carya & G. Smalley & USA \\
\hline & & & & & cordiformis & & \\
\hline & & EF070436 & BT & “ & “ & “ & “ \\
\hline & & EF070408 & $\mathrm{EF}$ & “ & “ & “ & “ \\
\hline \multirow[t]{7}{*}{ C. tanganyicensis } & CMW15992 & EU244999 & ITS & CBS122293 & A. mearnsii & R.N. Heath \& J. & Tanzania \\
\hline & & & & & & Roux & \\
\hline & & EU244971 & BT & “ & “ & “ & “ \\
\hline & & EU244931 & $\mathrm{EF}$ & “ & “ & “ & “ \\
\hline & CMW15999 & EU244998 & ITS & CBS122294 & “ & “ & “ \\
\hline & & EU244970 & BT & “ & “ & “ & “ \\
\hline & & EU244939 & $\mathrm{EF}$ & “ & “ & “ & “ \\
\hline \multirow[t]{6}{*}{ C. tribiliformis } & CMW13015 & AY529004 & ITS & CBS115949 & Pinus mercusii & M.J. Wingfield & Indonesia \\
\hline & & AY528994 & BT & “ & “ & “ & “ \\
\hline & & AY529015 & $\mathrm{EF}$ & “ & “ & “ & “ \\
\hline & CMW13013 & AY529003 & ITS & CBS115866 & P. mercusii & M.J. Wingfield & Indonesia \\
\hline & & AY528993 & BT & “ & “ & “ & “ \\
\hline & & AY529014 & $\mathrm{EF}$ & “ & “ & “ & “ \\
\hline \multirow[t]{8}{*}{ C. tsitsikammensis } & CMW14276 & EF408555 & ITS & CBS121018 & Rapanea & G.NK. Kamgan & South Africa \\
\hline & & & & & melanophloeos & \& J. Roux & \\
\hline & & EF408569 & $\mathrm{BT}$ & “ & “ & “ & “ \\
\hline & & EF408576 & $\mathrm{EF}$ & “ & “ & “ & “ \\
\hline & CMW14278 & EF408556 & ITS & CBS121019 & $R$ & G.NK. Kamgan & South Africa \\
\hline & & & & & melanophloeos & \& J. Roux & \\
\hline & & EF408570 & BT & “ & “ & “ & “ \\
\hline & & EF408577 & $\mathrm{EF}$ & “ & “ & “ & “ \\
\hline \multirow[t]{2}{*}{ C. tyalla } & ${ }^{*} \mathrm{CMW} 28932$ & HM071900 & ITS & CBS128703 & E. dunnii & G.NK. Kamgan & Australia \\
\hline & & HM071913 & BT & “ & “ & “ & $،$ \\
\hline
\end{tabular}




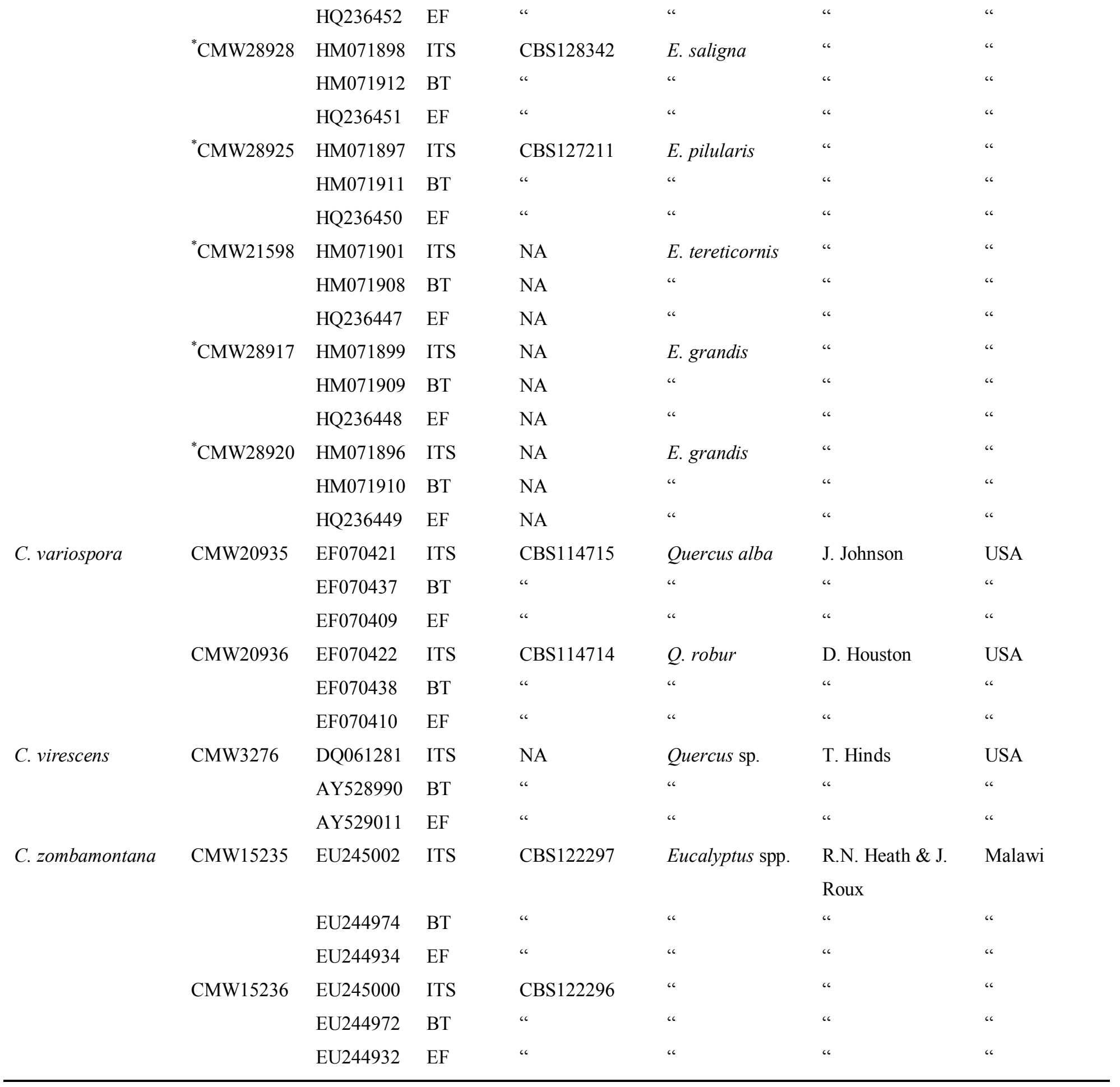




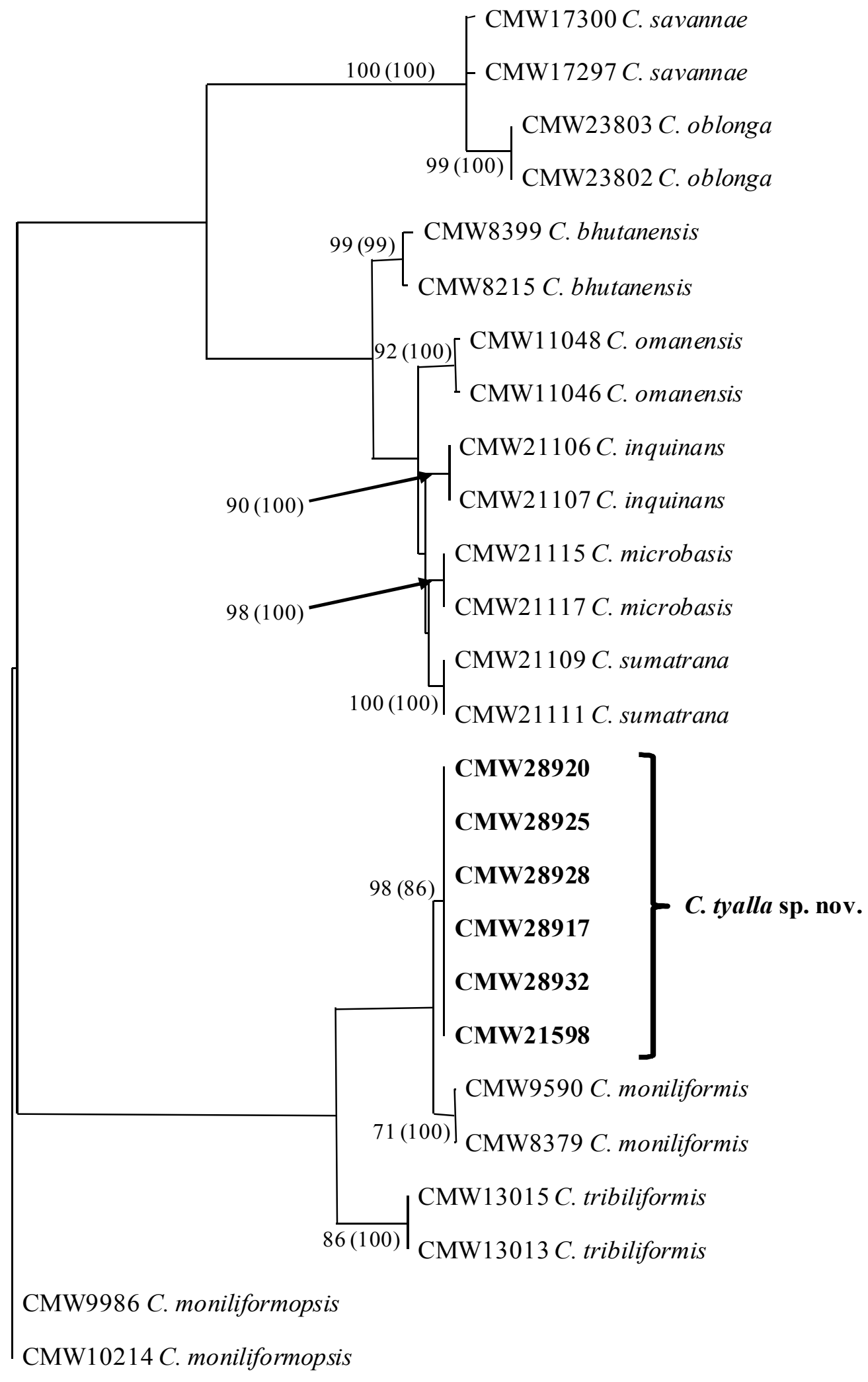

Fig. 1 Phylogenetic tree produced from a heuristic search of the combined ITS, BT and TEF sequence data, showing the relationship between C. tyalla sp. nov. from Eucalyptus trees in Australia and other Ceratocystis spp. resembling $C$. moniliformis. C. virescens was used as out-group taxon. Bootstrap values were derived from 1000 replicates and are indicated next to each clade with posterior probability values in brackets. 


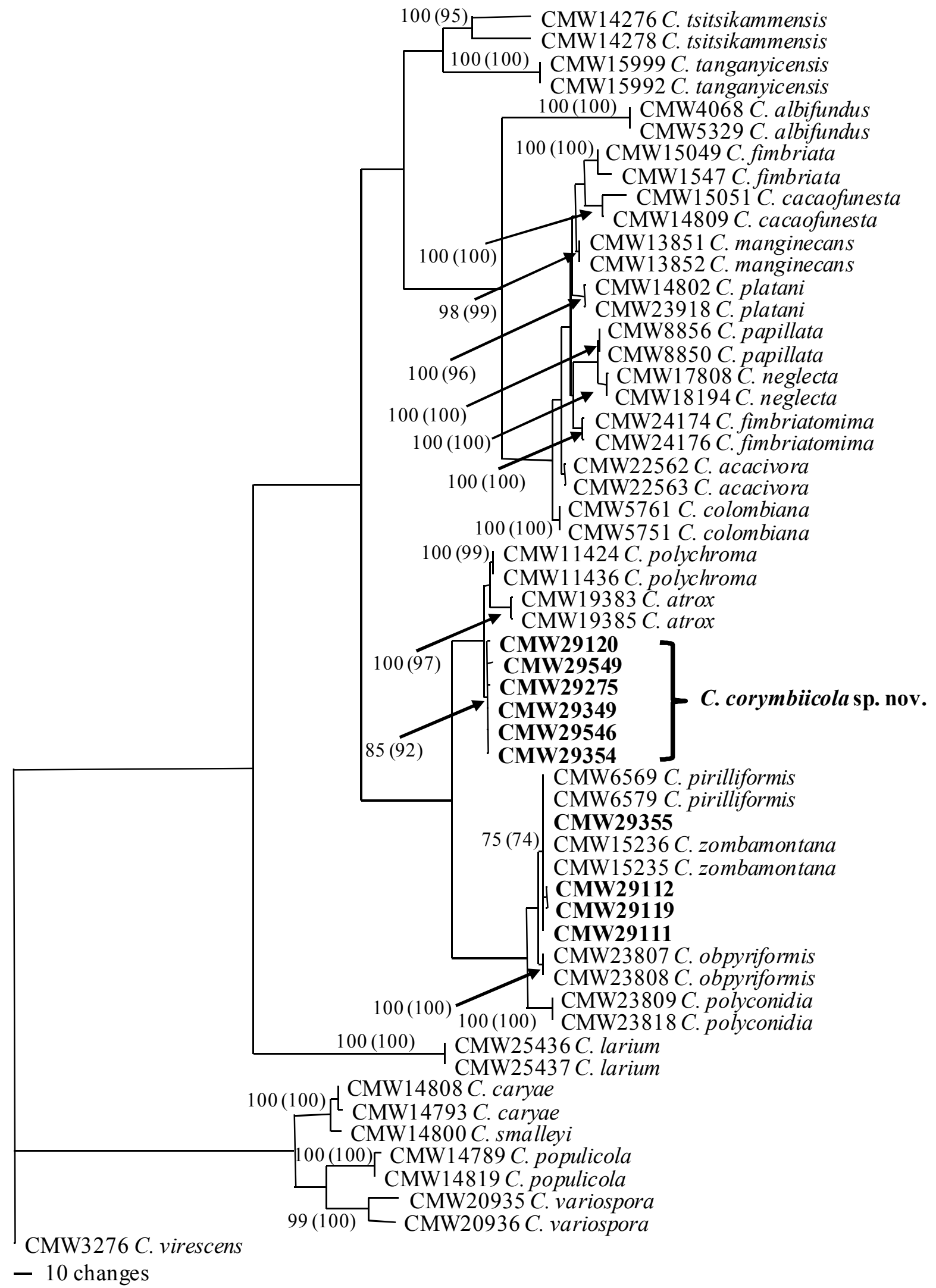

Fig. 2 Phylogenetic tree produced from a heuristic search of the combined ITS, BT and TEF sequence data, showing the relationship between C. corymbiicola sp. nov. from eucalypt trees in Australia and other Ceratocystis spp. resembling C. fimbriata. C. virescens was used as out-group taxon. Bootstrap values were derived from 1000 replicates and are indicated next to each clade with the posterior probability values in brackets. 


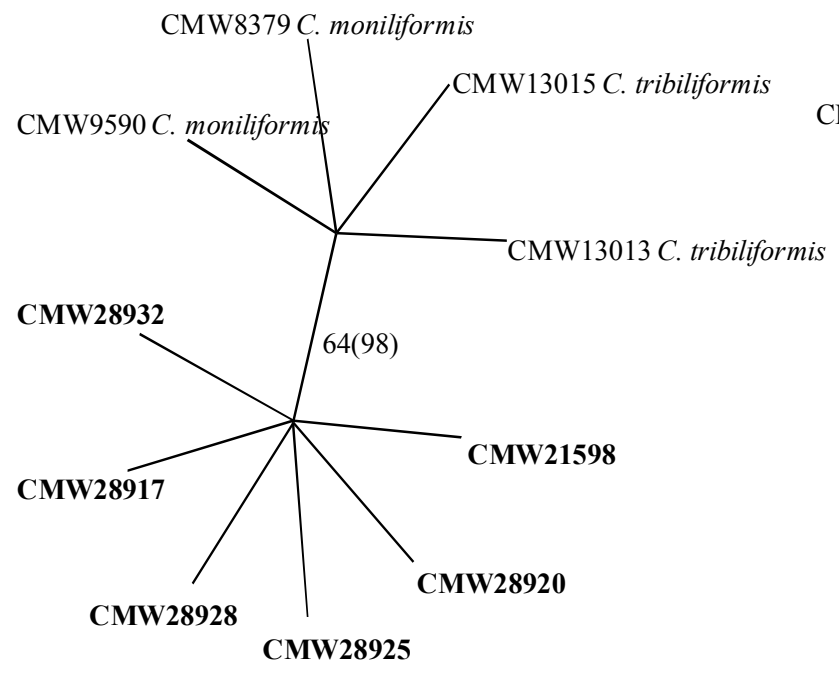

A

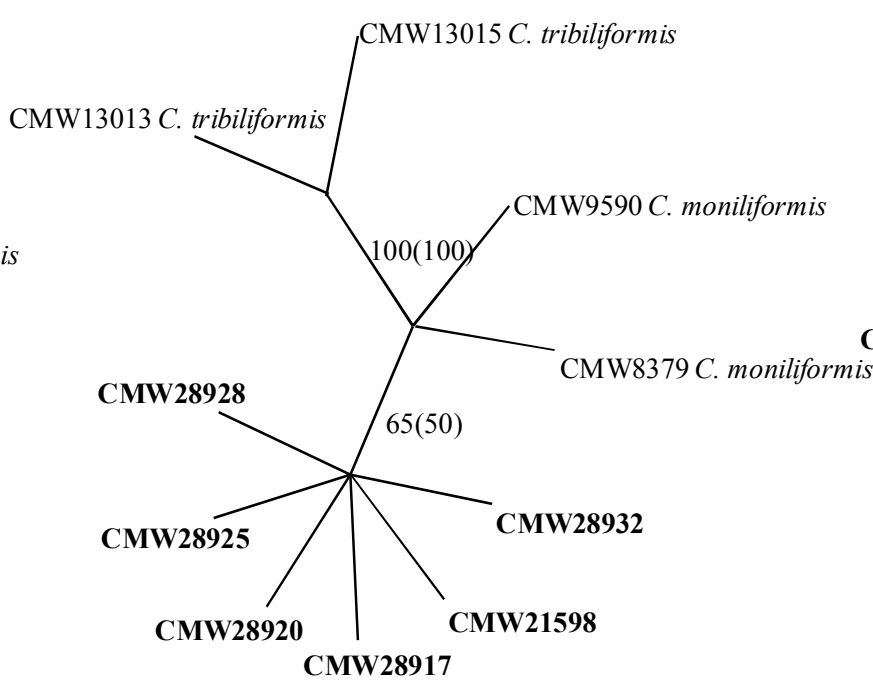

B

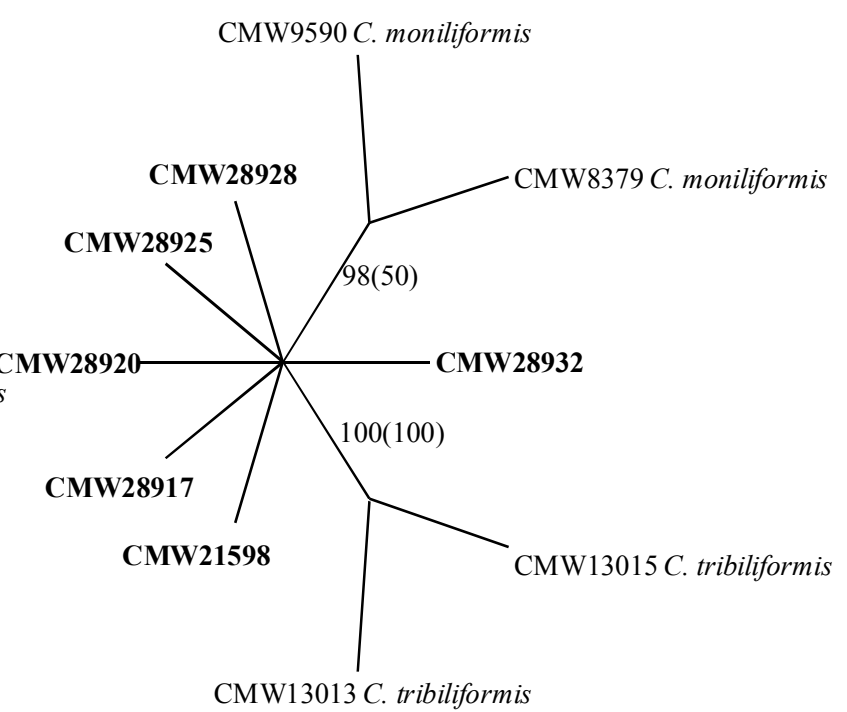

C

Fig. 3 Unrooted maximum parsimony tree produced from a heuristic search of the ITS (A) BT (B) and TEF (C) sequence data respectively, showing the relationship between $C$. tyalla sp. nov. (isolates in bold font type) from Eucalyptus trees in Australia and its most closely related neighbor in the C. moniliformis s.l. species complex. Bootstrap values were derived from 1000 replicates and are indicated next to each clade with Bayesian posterior probability values in brackets. 


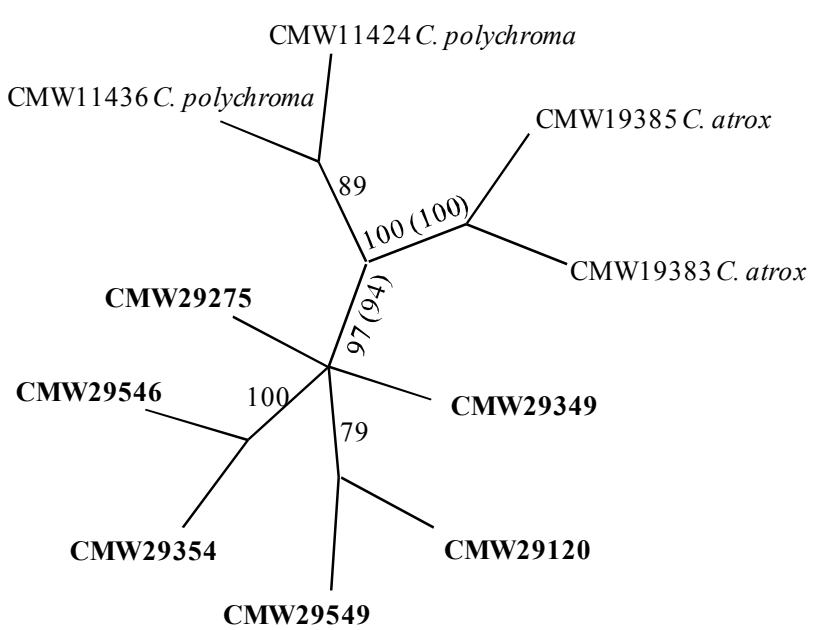

A

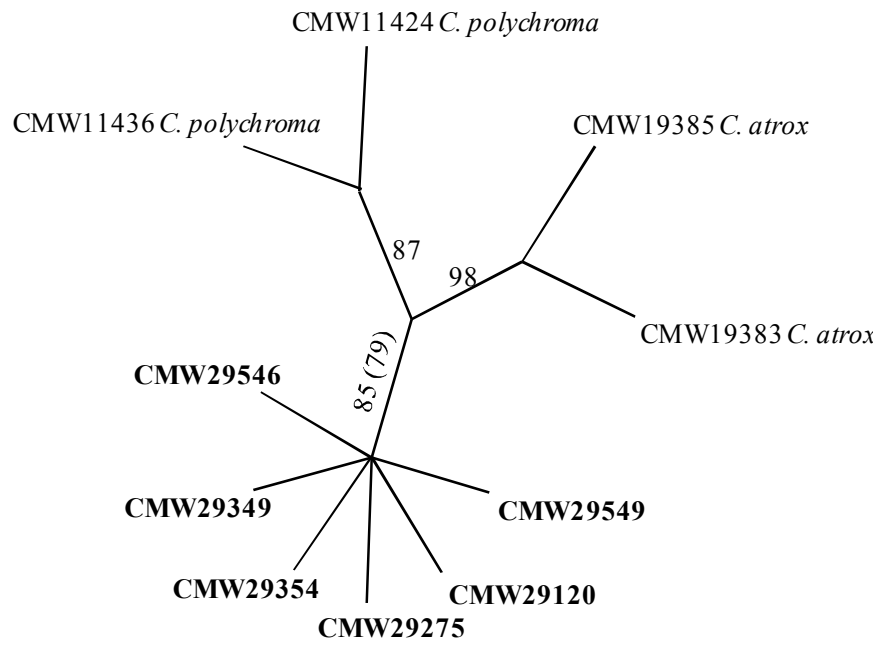

B

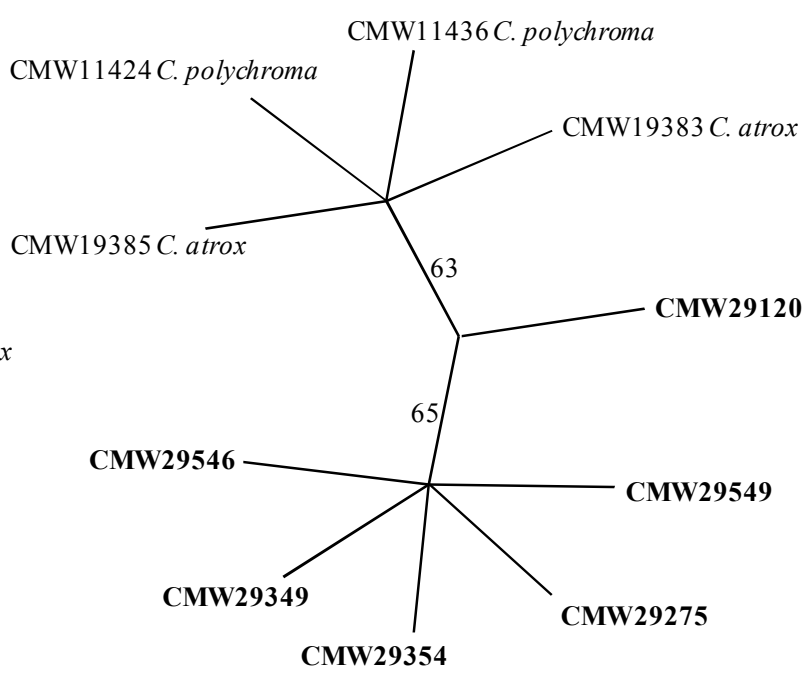

C

Fig. 4 Unrooted maximum parsimony tree produced from a heuristic search of the ITS (A) BT (B) and TEF (C) sequence data respectively, showing the relationship between $C$. corymbiicola sp. nov. (isolates in bold font type) from Eucalyptus trees in Australia and its most closely related neighbor in the C. fimbriata s.l. species complex. All isolates sequenced are in bold type. Bootstrap values were derived from 1000 replicates and are indicated next to each clade with Bayesian posterior probability values in brackets. 


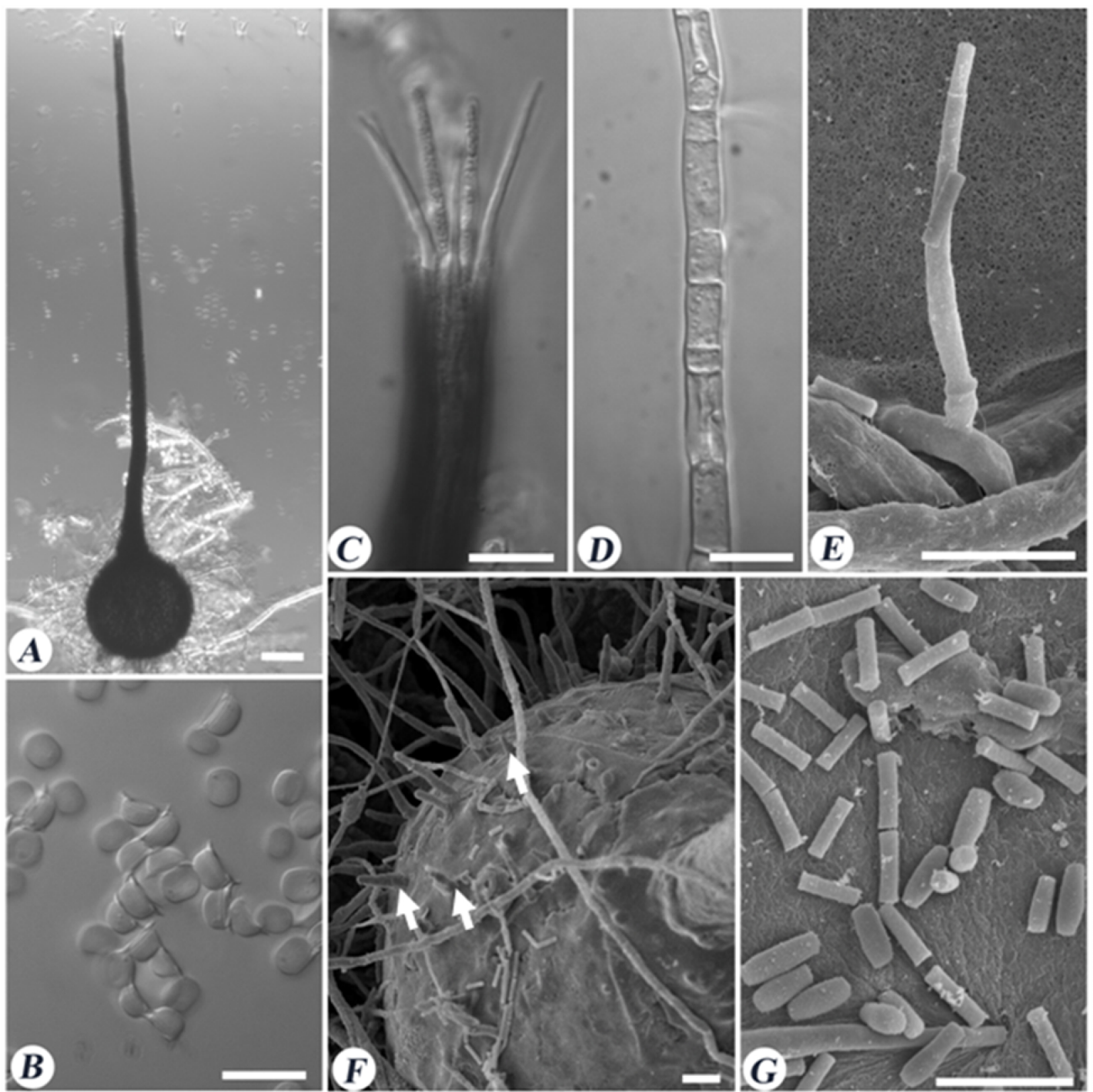

Fig. 5 Morphological characteristics of Ceratocystis tyalla sp. nov. A) Globose ascomatal base (scale bar $=50 \mu \mathrm{m}$ ), B) Hat-shaped ascospores (scale bar $=10 \mu \mathrm{m}) \mathrm{C}$ ) Divergent ostiolar hyphae (scale bar $=10 \mu \mathrm{m})$, D) Septate hyphae (scale bar $=10 \mu \mathrm{m})$ E) Phialidic conidiogenous cell with emerging conidia (scale bar $=10 \mu \mathrm{m})$, F) Ascomatal base with conical spines (scale bar $=10 \mu \mathrm{m}), \mathrm{G})$ Oblong conidia with obtuse end and bacilliform shaped conidia (scale bar $=10$ $\mu \mathrm{m})$. 


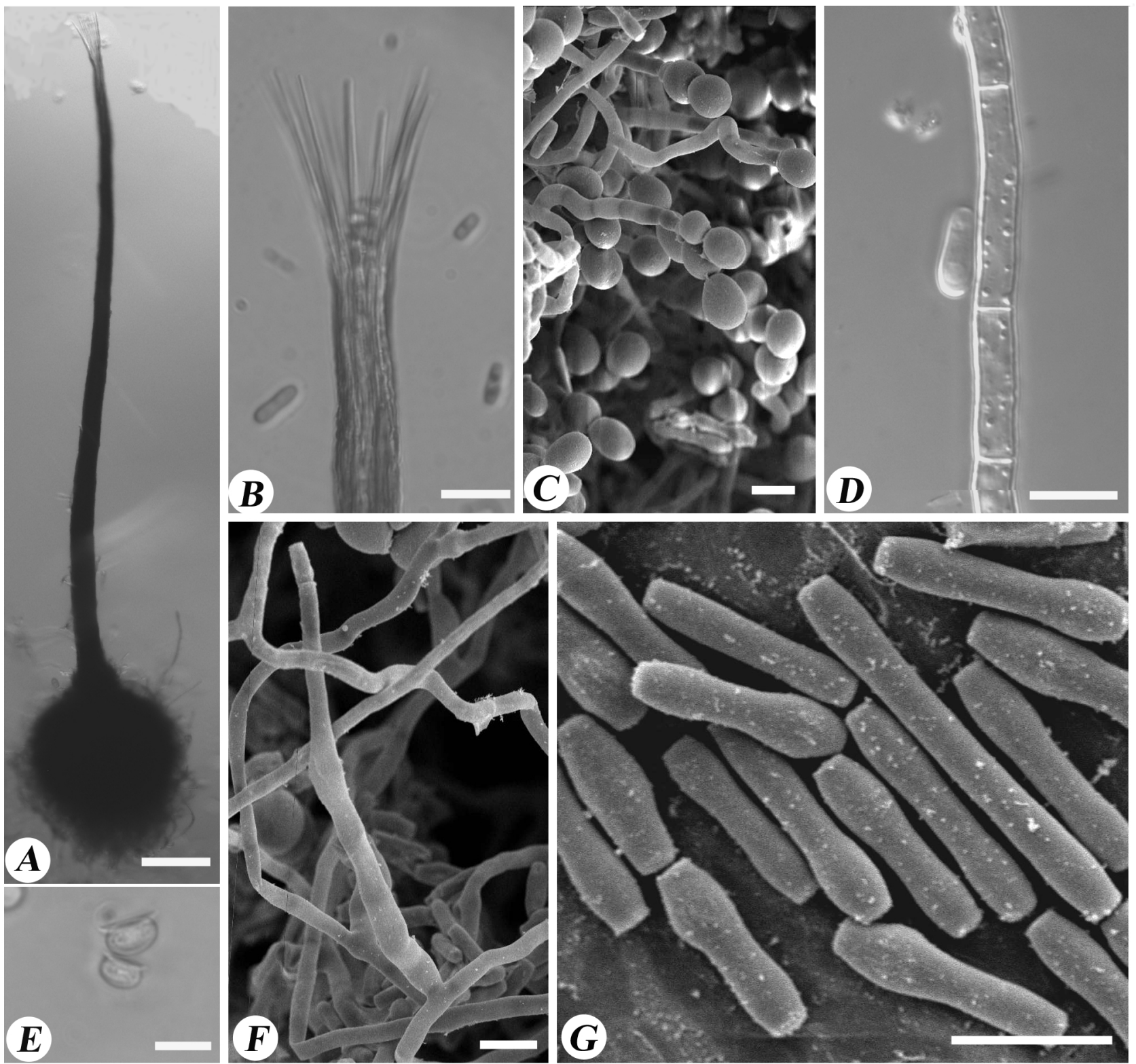

Fig. 6 Morphological characteristics of Ceratocystis corymbiicola sp. nov. A) Globose ascomatal base (scale bar $=100$ $\mu \mathrm{m}), \mathrm{B})$ Divergent ostiolar hyphae (scale bar $=20 \mu \mathrm{m}$ ), C) Ovoid chlamydospores (scale bar $=10 \mu \mathrm{m}$ ), D) Septate hyphae (scale bar $=10 \mu \mathrm{m})$, E), Hat-shaped ascospores in side view (scale bar $=10 \mu \mathrm{m})$, F) Phialidic conidiogenous cell with emerging bacilliform conidia (scale bar $=10 \mu \mathrm{m}$ ), G) Bacilliform shaped conidia with obtuse end and bacilliform shaped conidia with round bases (scale bar $=10 \mu \mathrm{m}$ ). 
Eucalyptus grandis_Mean bark lesion

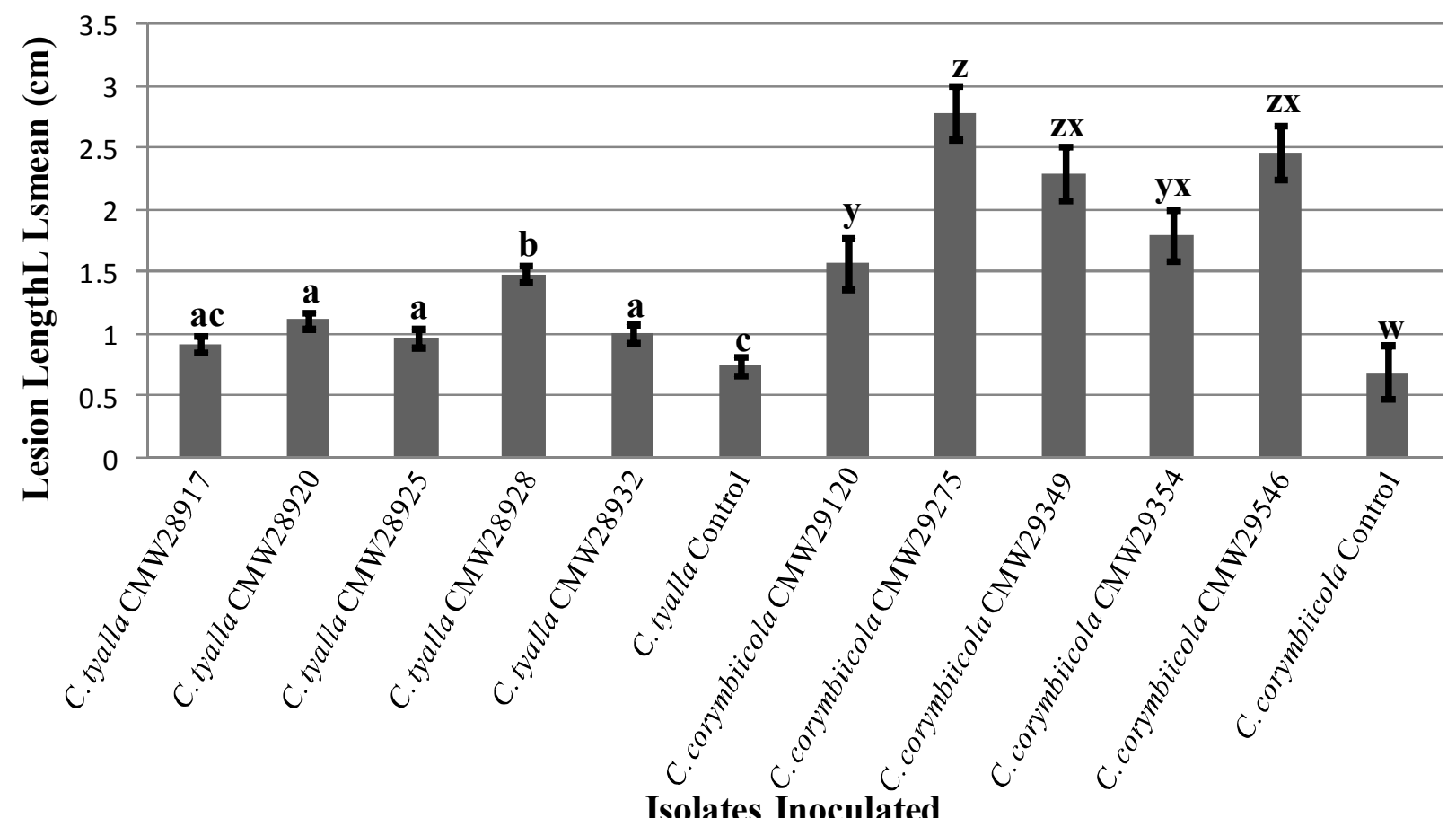

Fig. 7 Vertical bar chart showing results of inoculation trial (bark lesion) with C. tyalla isolates (CMW28917, 28920, 28925, 28928, 28932) on E. grandis trees. Lsmean $=1.05, \mathrm{R}=0.54, \mathrm{CV}=21.2, \mathrm{P}<0.0001$, Significance level $=0.05$. Average lesion lengths (0.93-1.49) cm; and with C. corymbiicola isolates (CMW29120, 29275, 29349, 29354, 29546) on $E$. grandis trees. Lsmean $=1.94, \mathrm{R}=0.54, \mathrm{CV}=34.45, \mathrm{P}<0.0001$, Significance level $=0.05$. Average lesion lengths $(1.58-2.79) \mathrm{cm}$. Lsmeans with similar letters are not statistically significant while those with different letters are statistically significant 


\section{Eucalyptus grandis_Mean xylem lesion}

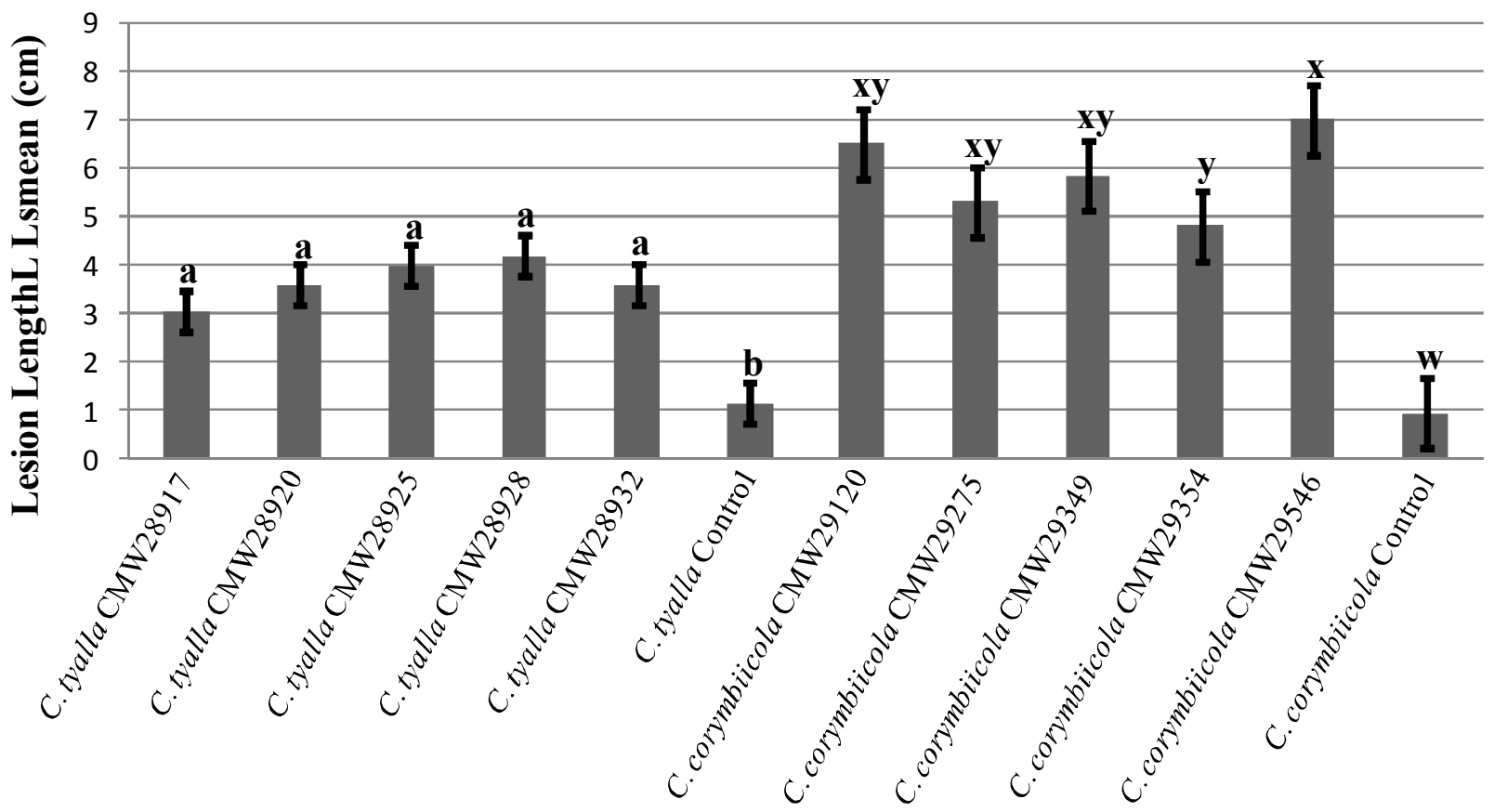

Isolates Inoculated

Fig. 8 Vertical bar chart showing results of inoculation trial (xylem lesion) with C. tyalla (CMW28917, 28920, 28925, 28928 , 28932) on E. grandis trees. Lsmean $=3.27, \mathrm{R}=0.39, \mathrm{CV}=40.97, \mathrm{P}<0.0001$, Significance level $=0.05$. Average lesion lengths (3.05-4.2) cm; and with C. corymbiicola (CMW29120, 29275, 29349, 29354, 29546) on E. grandis trees. Lsmean $=5.06, \mathrm{R}=0.46, \mathrm{CV}=44.76, \mathrm{P}<0.0001$, Significance level $=0.05$. Average lesion lengths $(4.8-7) \mathrm{cm}$. Lsmeans with similar letters are not statistically significant while those with different letters are statistically significant. 